Check for updates

Cite this: RSC Adv., 2018, 8, 38995

Received 30th September 2018 Accepted 14th November 2018

DOI: $10.1039 / \mathrm{c} 8 \mathrm{ra0} 0138 \mathrm{~g}$

rsc.li/rsc-advances

\title{
Synthesis and biological study of acridine-based imidazolium salts $\uparrow$
}

\author{
Olla Sharhan, ${ }^{* a b}$ Thorsten Heidelberg, (D) *a Najiahah Mohd Hashim, ${ }^{\text {cd }}$ \\ Abbas Abdulameer Salman, ${ }^{\text {ae }}$ Hapipah Mohd Ali $^{\mathrm{a}}$ and Soher Nagi Jayash ${ }^{\mathrm{fg}}$
}

A new series of acridine based imidazolium salts was synthesized and evaluated for in vitro cytotoxicity against human cancer cell lines by an MTT assay. The synthesis applied a coupling of imidazoles with 9chloroacridines, which originated from an Ullmann condensation of a 2-chloro-benzoic acid with an aniline. The target compounds were obtained in high yields. The DPPH assay indicated considerable antioxidant activity for target compounds with simple and short alkyl chains on the imidazole, while increasing chain length and the introduction of an additional $\pi$-electron system in most cases reduced the activity. All compounds exhibited low biotoxicity against non-cancerous cell lines, whereas a few compounds showed promising anticancer activity. Unlike for the reference drugs Tamoxifen and Paclitaxel, the anticancer activity of acridine imidazolium ions is specific for only selected cancer types. Reasonable fluorescent behaviour of the products provide potential for visualization of the distribution of active drugs in tissue.

\section{Introduction}

Cancer has become a major cause of mortality, leading to an urgent need for more effective anticancer drugs..$^{1-6}$ The development of new anticancer drugs and efficient treatment strategies for cancer are, hence, of great importance. ${ }^{7}$ 9Chloroacridine and its derivatives have received interest as a core structure of potential new therapeutics due to a broad biological property spectrum, covering both anticancer and antibacterial activities. ${ }^{8}$ Acridine-based natural products and synthetic derivatives containing imidazole as a second heterocyclic component have found wide use for medicinal applications based on biological and pharmacological activities as antioxidant, antimalarial and antitumor agents. ${ }^{3}$ Acridine and its derivatives are typical intercalative agents for DNA, causing their antitumor activity in chemotherapy. Recently several reviews on acridine derivatives have been published, focusing

${ }^{a}$ Chemistry Department, Faculty of Science, University of Malaya (UM), 50603 Kuala Lumpur, Malaysia.E-mail: heidelberg@um.edu.my; olla_sh@yahoo.com ${ }^{b}$ Chemistry Department, Faculty of Education, Thamar University, Yemen 'Department of Pharmacy, Faculty of Medicine, University of Malaya, Malaysia ${ }^{a}$ Centre for Natural Products and Drug Discovery (CENAR), Faculty of Science, University of Malaya, Malaysia

${ }^{e}$ College of Pathological Analysis Technologies, Al-Bayan University, Baghdad, Iraq ${ }^{f}$ Department of Restorative Dentistry, Faculty of Dentistry, University of Malaya, Malaysia

${ }^{g}$ Department of Oral Medicine and Periodontology, Faculty of Dentistry, Ibb University, Yemen

$\dagger$ Electronic supplementary information (ESI) available: Covering synthetic procedures of literature known precursors as well as images of NMR spectra, is available. See DOI: 10.1039/c8ra08138g on their therapeutic potential against cancer and bacteria. ${ }^{9-11}$ They have attracted significant attention as anticancer and antioxidant agents. ${ }^{2,12}$ Natural acridine compounds and synthetic derivatives of 9-chloroacridine and $N$-substituted imidazole have shown a wide range of biological activities, especially antitumor directed. This is matched by reported bioactivities for imidazole and their derivatives, ${ }^{13}$ covering antitumor activity as well. ${ }^{14}$

Basant and co-worker have examined derivatives of acridine with side chains at positions 4 and 5 for inhibitory potential against TAR DNA-binding protein 43 (TDP-43). ${ }^{15}$ Stable Nheterocyclic carbenes (NHCs) are readily accessible from imidazolium compounds. ${ }^{16}$ These secondary derivatives have been reported as effective ligands for certain palladium-catalysed reactions. ${ }^{17}$ The purpose of this study, however, focussed on the synthesis of $N$-substituted acridine-based imidazolium salts and the investigation of their anticancer activities. Introduction of imidazolium ions on acridine can substantially increase the poor water solubility, as recently demonstrates by Raju et al. ${ }^{19}$ Several cancer-related patents for 9-amino-substituted acridines $^{18}$ suggest potential of 9-imidazolium-substituted derivatives. This is in line with experiments indicating substantial DNA binding of 9-amino-substituted acridines, although these systems did not contain ionic charges. ${ }^{1}$ In view of the wide medicinal application spectrum of acridine derivatives, we have also studies the antioxidant activity of the compounds using DPPH and FRAP assays, which may be used to guide antimicrobial investigation in future. The fluorescence behaviour of acridine led us to measure UV-Vis absorption and emission spectra as well to evaluate the possibility of potential 
monitoring of the distribution of acridine-based antitumor reagents in an organism.

\section{Results and discussion}

\section{Chemistry}

The synthesis of the compounds applied two alternative approaches, differing in the alkylation sequence of the imidazole building block. While acridine imidazolium salts with simple saturated hydrocarbon substituents were obtained by condensation of 6 -chloroacridines 3 with the respective alkylated imidazole $\mathbf{5 ,}^{\mathbf{2 0 - 2 2}}$ the introduction of more reactive substituents predominately applied derivatives of imidazolylacridine 6 and benzyl or phenacyl halides instead. The 6chloroacridine precursors 3 were obtained by Ullmann condensation of 2-chlorobenzoic acids 1 with anilines 2 .,2,23,24 $^{\mathbf{1 , 2}}$ The synthetic scheme is displayed in Scheme 1.

All compounds were obtained in respectable yields, as shown in Table 1. Structure confirmation applied IR and NMR spectroscopy $\left({ }^{1} \mathrm{H} \&{ }^{13} \mathrm{C}\right)$, as well as mass spectrometry (ESI in positive

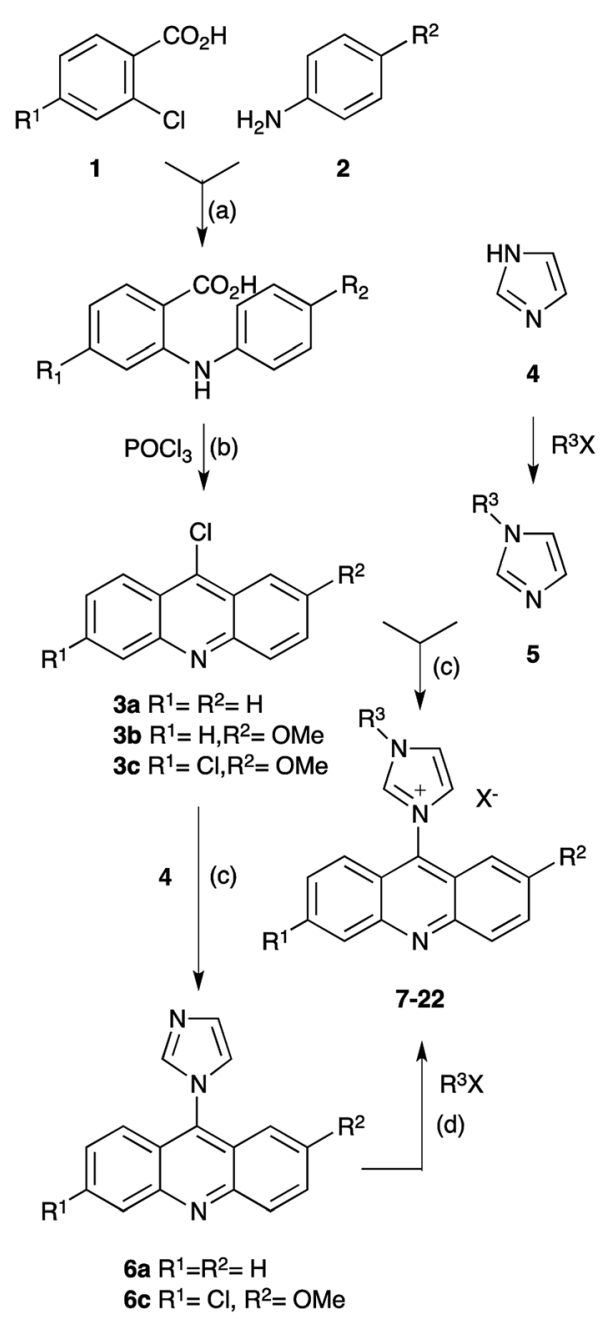

Scheme 1 Synthesis of acridine imidazolium salts. (a) $\mathrm{KI}, \mathrm{Cu}, \mathrm{K}_{2} \mathrm{CO}_{3}$, DMF, reflux, 6-8 h; (b) $\mathrm{POCl}_{3}, 135{ }^{\circ} \mathrm{C}, 70-85 \%$ (a \& b); (c) toluene, reflux, $15-18$ h, $70-85 \%$ : (d) $M e C N$, reflux, $12-48$ h, $85-95 \%$.
Table 1 Overview on synthetic compounds

\begin{tabular}{|c|c|c|c|c|c|c|}
\hline Compd. & Precursor & $\mathrm{R}^{1}$ & $\mathrm{R}^{2}$ & $\mathrm{R}^{3}$ & $\mathrm{X}$ & Yield \\
\hline $6 a$ & $3 a$ & $\mathrm{H}$ & $\mathrm{H}$ & - & - & $81 \%$ \\
\hline $6 c$ & $3 c$ & $\mathrm{Cl}$ & $\mathrm{OCH}_{3}$ & - & - & $79 \%$ \\
\hline 7 & $3 \mathbf{a}$ & $\mathrm{H}$ & $\mathrm{H}$ & $\mathrm{C}_{6} \mathrm{H}_{13}$ & $\mathrm{Cl}$ & $75 \%$ \\
\hline 8 & $3 \mathbf{b}$ & $\mathrm{H}$ & $\mathrm{OCH}_{3}$ & $\mathrm{CH}_{3}$ & $\mathrm{Cl}$ & $74 \%$ \\
\hline 9 & $3 \mathbf{b}$ & $\mathrm{H}$ & $\mathrm{OCH}_{3}$ & $\mathrm{C}_{4} \mathrm{H}_{9}$ & $\mathrm{Cl}$ & $77 \%$ \\
\hline 10 & $3 c$ & $\mathrm{Cl}$ & $\mathrm{OCH}_{3}$ & $\mathrm{CH}_{3}$ & $\mathrm{Cl}$ & $85 \%$ \\
\hline 11 & $3 c$ & $\mathrm{Cl}$ & $\mathrm{OCH}_{3}$ & $\mathrm{C}_{2} \mathrm{H}_{5}$ & $\mathrm{Cl}$ & $81 \%$ \\
\hline 12 & $3 c$ & $\mathrm{Cl}$ & $\mathrm{OCH}_{3}$ & $\mathrm{C}_{4} \mathrm{H}_{9}$ & $\mathrm{Cl}$ & $80 \%$ \\
\hline 13 & $3 c$ & $\mathrm{Cl}$ & $\mathrm{OCH}_{3}$ & $\mathrm{C}_{8} \mathrm{H}_{17}$ & $\mathrm{Cl}$ & $75 \%$ \\
\hline 14 & $6 a$ & $\mathrm{H}$ & $\mathrm{H}$ & $p \mathrm{Me}-\mathrm{Bn}$ & $\mathrm{Cl}$ & $85 \%$ \\
\hline 15 & $6 a$ & $\mathrm{H}$ & $\mathrm{H}$ & $p \mathrm{Br}-\mathrm{Bn}$ & $\mathrm{Br}$ & $90 \%$ \\
\hline 16 & $6 a$ & $\mathrm{H}$ & $\mathrm{H}$ & $o \mathrm{Br}-\mathrm{Bn}$ & $\mathrm{Br}$ & $91 \%$ \\
\hline 17 & $6 a$ & $\mathrm{H}$ & $\mathrm{H}$ & $p \mathrm{NO}_{2}-\mathrm{Bn}$ & $\mathrm{Br}$ & $91 \%$ \\
\hline 18 & $6 a$ & $\mathrm{H}$ & $\mathrm{H}$ & $\mathrm{BzCH}_{2}$ & $\mathrm{Br}$ & $91 \%$ \\
\hline 19 & $6 a$ & $\mathrm{H}$ & $\mathrm{H}$ & $p{\mathrm{Br}-\mathrm{BzCH}_{2}}_{2}$ & $\mathrm{Br}$ & $95 \%$ \\
\hline 20 & $3 \mathbf{c}$ & $\mathrm{Cl}$ & $\mathrm{OCH}_{3}$ & $\mathrm{Bn}$ & $\mathrm{Cl}$ & $80 \%$ \\
\hline 21 & $6 c$ & $\mathrm{Cl}$ & $\mathrm{OCH}_{3}$ & $\mathrm{BzCH}_{2}$ & $\mathrm{Br}$ & $90 \%$ \\
\hline 22 & $6 c$ & $\mathrm{Cl}$ & $\mathrm{OCH}_{3}$ & $p \mathrm{Br}^{-\mathrm{BzCH}_{2}}$ & $\mathrm{Br}$ & $85 \%$ \\
\hline
\end{tabular}

mode), while elemental analysis confirmed high purity of the compounds as required for the investigation of biological activity. All compounds exhibited poor solubility in water, but could be well dissolved in DMSO. Therefore tests for biological activity applied DMSO solutions.

\section{Antioxidant activity}

Antioxidants are substances that may protect cells from the damage caused by unstable molecules known as free radicals. Due to their highly chemical reactivity, free radical damage may lead to cancer. ${ }^{2526}$ Many biological effects of imidazolium compounds have been related to their antioxidant properties. ${ }^{27,28}$ Therefore the synthesized compounds were evaluated for their antioxidant activity. Antioxidant activity is a complex feature, reflecting different mechanistic pathways. ${ }^{29}$ These cannot be evaluated using a single test; typically two assays with different working principles are, hence, applied.

One of them determines the antioxidant activity by neutralization of coloured DPPH radicals via transfer of a hydrogen radical, leading to a discolouration that can be measured photometrically. ${ }^{30}$ The radical-focus of the assay reflects cellular damage processes caused by singlet and triplet oxygen, as well as decomposition of peroxides..$^{31,32}$

The results of the DPPH assay are summarized in Table 2. The data indicate reasonable good radical quenching activity for the non-substituted acridine imidazolium ion 7, comparable with the control compound ascorbic acid. The radical scavenging ability of 7 substantially exceeds that of the non-ionic precursor 6a. Since radicals are species of electron deficiency, it appears surprising that a cationic compound exhibits better radical scavenging potential than the non-ionic compound of a closely related structure. However, the alkylation of imidazole and its related ionization do not affect the conjugated $\pi$-electron system, since the utilized free electron pair is perpendicular to the $\pi$-system. On the other hand, the imidazolium cation exhibits a more pronounced resonance than the respective non- 
Table 2 Antioxidant activity ${ }^{a}$

\begin{tabular}{|c|c|c|}
\hline Compd. & $\mathrm{IC}_{50}(\mathrm{DPPH})\left[\mu \mathrm{g} \mathrm{mL}^{-1}\right]$ & FRAP $\left[\mu \mathrm{g} \mathrm{FE} \mathrm{mL}^{-1}\right.$ \\
\hline $6 \mathbf{a}$ & $164 \pm 3$ & $<100$ \\
\hline $6 c$ & $144 \pm 27$ & $<100$ \\
\hline 7 & $49 \pm 1$ & 108 \\
\hline 8 & $196 \pm 16$ & $<100$ \\
\hline 9 & $133 \pm 53$ & $<100$ \\
\hline 10 & $46 \pm 4$ & $<100$ \\
\hline 11 & $47 \pm 4$ & $<100$ \\
\hline 12 & $57 \pm 7$ & $<100$ \\
\hline 13 & $216 \pm 3$ & $<100$ \\
\hline 14 & $367 \pm 30$ & 211 \\
\hline 15 & $103 \pm 42$ & $<100$ \\
\hline 16 & $98 \pm 6$ & $<100$ \\
\hline 17 & $216 \pm 41$ & 201 \\
\hline 18 & $367 \pm 30$ & 211 \\
\hline 19 & $50 \pm 2$ & $<100$ \\
\hline 20 & $43 \pm 4$ & $<100$ \\
\hline 21 & $69 \pm 5$ & $<100$ \\
\hline 22 & $228 \pm 12$ & 170 \\
\hline $\mathrm{AA}$ & $41 \pm 2$ & 337 \\
\hline
\end{tabular}

${ }^{a}$ Data represent mean of 3 measurements; $\mathrm{AA}=$ ascorbic acid, $\mathrm{FE}=$ ferric equivalent.

ionic heterocycle. This is reflected in two resonance structures of almost identical energy, resulting in the distribution of the positive charge over the two ring nitrogen atoms, and probably explains the higher DPPH activity of 7 compared to $6 \mathbf{a}$.

Typically the distribution of radical character and electron deficiency over a compound structure, particularly mediated via resonance, stabilizes a radical and, hence potential increases the radical scavenging capacity of the mother-compound of the resulting radical. Therefore increased electron density in a compound is commonly associated with increasing radical stability. However, introduction of a methoxy substituent on the acridine in compounds $\mathbf{8}$ and $\mathbf{9}$ significantly lowered the antioxidant activity, whereas the subsequent introduction of a chloride appears to compensate this effect for compounds 10, 11 and 12. The substantially reduced radical scavenging potential of compound $\mathbf{1 3}$ cannot be explained by electronic effects, but may reflect solubility issues owing to the significantly increased length of the hydrophobic alkyl chain. The slightly lower activity of $\mathbf{1 2}$ compared to $\mathbf{1 0}$ and $\mathbf{1 1}$ is in line with this explanation.

The introduction of an additional methylene-linked $\pi$-electron system at the imidazole in compounds 14-22 potentially increases the conjugation system of radical species, if the $\mathrm{H}$ transfer affects the methylene linker. However, the high DPPH $\mathrm{IC}_{50}$ values for compounds $\mathbf{1 4 - 1 8}$ and $\mathbf{2 2}$ suggest either a different preferred site of interaction, e.g. the $\mathrm{CH}$ in between the two nitrogen atoms of the imidazole ring, or reflect hydrophobic effects as well. Within the compounds that comprised of two methylene-isolated $\pi$-electron systems, only 19, 20, and perhaps 21, exhibited highly efficient radical scavenging ability according to the DPPH assay.

The second method for the determination of antioxidant activity applied the FRAP assay. It measures the capacity of a substance to reduce oxidative species, thereby changing the colour, which is determined spectrophotometrically. ${ }^{29}$ Unlike for DPPH, the FRAP assay does not emphasize on radical reactions, but focuses on single electron exchange processes. It measures the antioxidant activity via reduction of ferric $\left(\mathrm{Fe}^{3+}\right)$ to ferrous $\left(\mathrm{Fe}^{2+}\right)$ ions, visualized by the coloured ferrous-tripyridyltriazine complex.

Almost all compounds exhibited rather low antioxidant activities according to the FRAP assay compared with the applied reference compound, ascorbic acid. In view of this behaviour and in consideration of the poor correlation of the FRAP and DPPH assay results, the analysis of antioxidant activity was limited to the DPPH assay.

\section{Biological activity}

The potential cytotoxicity of all synthesized substituted acridine-imidazolium salt derivatives was evaluated in vitro against a panel of human cancer cell lines. The panel consisted of breast cancer cells (MCF-7), prostate adenocarcinoma cells (PC-3), ovarian cancer cells (CAOV-3), non-tumorigenic ovarian cell line (T1074) and non-tumorigenic breast cell line (MCF10a). Tamoxifen and Paclitaxel were used as the reference drug for positive control. The results are summarized in Table 3.

Practically all acridine-based imidazolium salts exhibited unproblematic cell-toxicity against non-cancer cell lines with $\mathrm{IC}_{50}$ values above $50 \mu \mathrm{g} \mathrm{mL}^{-1}$. This suggests that the compounds can be safely utilized for cancer therapy, provided that the imidazolium-acridines do not exhibit problematic mutagenic activity, which was not evaluated in the

Table 3 In vitro cell toxicity after $24 \mathrm{~h}$ exposure $^{a}$

\begin{tabular}{|c|c|c|c|c|c|}
\hline \multirow[b]{3}{*}{ Compd. } & \multicolumn{5}{|c|}{$\mathrm{IC}_{50}\left[\mu \mathrm{g} \mathrm{mL}^{-1}\right]$} \\
\hline & \multicolumn{3}{|c|}{ Cancer cell-lines } & \multicolumn{2}{|c|}{ Non-cancer cell-lines } \\
\hline & CAOV-3 & PC-3 & MCF-7 & T1074 & MCF-10a \\
\hline $6 a$ & $12 \pm 1$ & $6 \pm 1$ & $28 \pm 2$ & $40 \pm 7$ & $49 \pm 9$ \\
\hline $6 \mathrm{c}$ & $68 \pm 5$ & $77 \pm 13$ & $21 \pm 1$ & $73 \pm 16$ & $66 \pm 9$ \\
\hline 7 & $80 \pm 2$ & $71 \pm 7$ & $9 \pm 1$ & $90 \pm 8$ & $67 \pm 3$ \\
\hline 8 & $2.5 \pm 0.4$ & $68 \pm 4$ & $41 \pm 4$ & $87 \pm 12$ & $70 \pm 11$ \\
\hline 9 & $12 \pm 2$ & $62 \pm 5$ & $49 \pm 3$ & $86 \pm 8$ & $50 \pm 1$ \\
\hline 10 & $77 \pm 5$ & $76 \pm 18$ & $53 \pm 5$ & $66 \pm 15$ & $82 \pm 5$ \\
\hline 11 & $60 \pm 1$ & $92 \pm 13$ & $23 \pm 2$ & $78 \pm 10$ & $98 \pm 5$ \\
\hline 12 & $6 \pm 1$ & $75 \pm 10$ & $38 \pm 5$ & $89 \pm 6$ & $>50$ \\
\hline 13 & $24 \pm 12$ & $28 \pm 7$ & $36 \pm 7$ & $54 \pm 9$ & $>50$ \\
\hline 14 & $22 \pm 1$ & $9 \pm 1$ & $17 \pm 2$ & $154 \pm 22$ & $97 \pm 2$ \\
\hline 15 & $4.5 \pm 0.7$ & $29 \pm 1$ & $24 \pm 8$ & $64 \pm 9$ & $>50$ \\
\hline 16 & $>50$ & $12 \pm 6$ & $42 \pm 2$ & $46 \pm 5$ & $94 \pm 26$ \\
\hline 17 & $86 \pm 10$ & $12 \pm 2$ & $56 \pm 12$ & $139 \pm 21$ & $71 \pm 14$ \\
\hline 18 & $63 \pm 6$ & $93 \pm 7$ & $43 \pm 7$ & $75 \pm 16$ & $>50$ \\
\hline 19 & $12 \pm 2$ & $87 \pm 5$ & $22 \pm 5$ & $88 \pm 6$ & $50 \pm 2$ \\
\hline 20 & $27 \pm 2$ & $99 \pm 7$ & $\mathbf{5} \pm \mathbf{1}$ & $83 \pm 11$ & $83 \pm 20$ \\
\hline 21 & $5 \pm 2$ & $79 \pm 9$ & $22 \pm 4$ & $75 \pm 17$ & $85 \pm 10$ \\
\hline 22 & $23 \pm 5$ & $24 \pm 8$ & $20 \pm 2$ & $84 \pm 5$ & $87 \pm 2$ \\
\hline Tamoxifen & $2 \pm 1$ & $2 \pm 1$ & $11 \pm 1$ & $78 \pm 7$ & $85 \pm 6$ \\
\hline Paclitaxel & $4.8 \pm 1$ & $5 \pm 1$ & $6 \pm 1$ & $>50$ & $75 \pm 2$ \\
\hline
\end{tabular}

${ }^{a}$ Data represent mean of 3 measurements. 
investigation. A potential exception, however, is compound 16, which showed a slightly lower $\mathrm{IC}_{50}$ against $\mathrm{T} 1074$. Interestingly the activity against cancer cell lines varied significantly for the different cell lines, thereby limiting potential applications to only one specific cancer type. This selectivity, mismatching the more generic profile of Tamoxifen and Paclitaxel, disfavours a pharmaceutical application. The reason for this are separate clinical tests for several drugs with limited application spectrum.

Compound 8 showed high activity against ovarian cancer, surpassing Paclitaxel and practically matching Tamoxifen. However, $\mathbf{8}$ was practically inactive against prostate and breast cancer. Similar profiles, but with less drastic extremes, were observed for compounds 12, 15 and 21. A comparison of the structures of these active compounds furnished no distinct lead structure, as the active compounds differ in both the acridine core and the imidazole substitution. A structure-activity relation analysis of compounds 7-13, reflecting simple alkyl chain on the imidazole, suggests a medium chain length for the imidazole alkylation and single methoxy-substitution of the acridine as lead structure. The data for compounds 14-22, indicate that the incorporation of aromatic structures at the imidazolium substituent can benefit the activity as well. However, the activity is sensitive towards minor changes in the substitution at the aromatic ring. Overall the activity data for CAOV-3 probably indicate considerable steric constraints for a medium sized substituent at the imidazole, whereas the electronic nature of the alkyl substituent is not of primary relevant.

Varying cytotoxicity has been associated with a variety of rationales, involving charge distribution and water solubility. ${ }^{33,34}$ Particularly effects of chain lengths have been investigated. ${ }^{35}$ However, the obtained data for the CAOV-3 activity of acridine-based imidazolium salts are insufficient to speculate on a rational.

The cytotoxic activity against prostate cancer was rather discouraging. The most active compound was the non-ionic imidazolium-precursor 6a, while only compound 14 exhibited a somehow reasonable, though considerably lower activity compared with the positive controls. The predominately low bioactivities against PC-3 render a structure-activity relation study non-suitable.

Promising breast cancer activity was found for compounds 7 and especially 20, which was more active than any of the positive controls. However, the structural differences of these two compounds do not enable the creation of a lead structure. The same applies for trends, because of the commonly low bioactivity of compounds against MCF-7.

\section{Fluorescence}

Acridine and its derivatives show fluorescence. This feature might be useful to monitor the distribution of acridine based drugs in in vivo investigations. Therefore we investigated the fluorescence behaviour of the acridine-based imidazolium salts. The investigation started with the recording of UV-Vis spectra. The wavelength for the maximum at highest wavelength was chosen for the excitation. The fluorescence investigation was conducted at a fixed concentration of $12 \mu \mathrm{mol} \mathrm{L}^{-1}$ in acetonitrile-water to account for the insufficient solubility in water. Two different shapes were found for the fluorescence spectra, which are shown in Fig. 1. The results are summarized in Table 4.

All compounds only required low energy UV-light for excitation. The blue fluorescence of the sample could easily be visualized using the long wavelength of a standard laboratory UV lamp. Substitution of acridine with an imidazole changes the emission spectrum. ${ }^{19}$ The observed spectra are in line with previously reported 9-amino-substituted acridines, ${ }^{36-38}$ as well as with documented $\pi^{*} \rightarrow \pi$ and $\pi^{*} \rightarrow \mathrm{n}$ transitions for derivatives of 6,9-dichloro-acridine. ${ }^{\mathbf{1} 39}$ Acridine imidazolium cations containing a non-substituted acridine core and substituents involving conjugated systems at the imidazole exhibited double peak fluorescence spectra according to type B in Fig. 1. These peaks have been associated with $\pi^{*} \rightarrow \pi$ transitions on the imidazole and $\pi^{*} \rightarrow \mathrm{n}$ transitions on both the imidazole and the acridine. ${ }^{40}$ Most of the other compounds, on the other hand, only showed a broad single peak emission, reflecting spectrum type A in Fig. 1. The noticeable red shift of spectra type A may reflect an increased conjugation system due

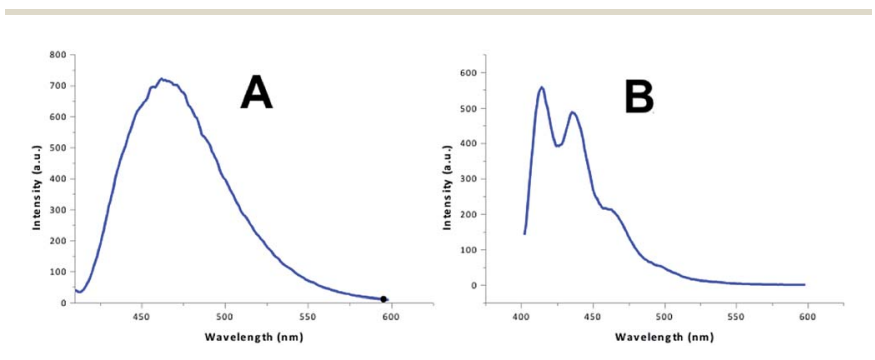

Fig. 1 Fluorescence spectra.

Table 4 Fluorescence behaviour ${ }^{a}$

\begin{tabular}{lllll} 
Compd. & $\lambda_{\text {max abs } \lambda_{\text {exc }}[\mathrm{nm}]}$ & Spect $_{\text {em }}$ & $\lambda_{\max \text { em }}[\mathrm{nm}]$ & Int $_{\text {em }}[\mathrm{AU}]$ \\
\hline $\mathbf{3 c}$ & 405 & $\mathrm{~A}$ & 451 & 732 \\
$\mathbf{6 a}$ & 389 & $\mathrm{~B}$ & 416,440 & 493,462 \\
$\mathbf{6 c}$ & 400 & $\mathrm{~A}$ & 455 & 774 \\
$\mathbf{7}$ & 410 & $\mathrm{~A}$ & 458 & 856 \\
$\mathbf{8}$ & 400 & $\mathrm{~A}$ & 465 & 714 \\
$\mathbf{9}$ & 401 & $\mathrm{~B}$ & 415,436 & 553,488 \\
$\mathbf{1 0}$ & 407 & $\mathrm{~A}$ & 450 & 761 \\
$\mathbf{1 1}$ & 411 & $\mathrm{~A}$ & 471 & 456 \\
$\mathbf{1 2}$ & 410 & $\mathrm{~A}$ & 464 & 640 \\
$\mathbf{1 3}$ & 403 & $\mathrm{~A}$ & 464 & 720 \\
$\mathbf{1 4}$ & 392 & $\mathrm{~B}$ & 420,435 & 319,323 \\
$\mathbf{1 5}$ & 387 & $\mathrm{~B}$ & 421,438 & 571,582 \\
$\mathbf{1 6}$ & 387 & $\mathrm{~A}$ & 461 & 191 \\
$\mathbf{1 7}$ & 386 & $\mathrm{~B}$ & 416,448 & 427,409 \\
$\mathbf{1 8}$ & 384 & $\mathrm{~B}$ & 414,438 & 608,540 \\
$\mathbf{1 9}$ & 385 & $\mathrm{~B}$ & 416,440 & 436,396 \\
$\mathbf{2 0}$ & 408 & $\mathrm{~A}$ & 465 & 756 \\
$\mathbf{2 1}$ & 409 & $\mathrm{~A}$ & 450 & 798 \\
$\mathbf{2 2}$ & 408 & $\mathrm{~A}$ & 443 & 947 \\
$a$ & & &
\end{tabular}


to the acridine substitution. Unlike for $N$-arylated imidazolium cations, ${ }^{41}$ no significant differences were observed between substituents with and without conjugated systems at the imidazole. This can be related to the breaking of conjugation due to the methylene linkage. In terms of fluorescence intensity only a moderate variation was found between the systems. An exception to this, however, is found at compound 16, which exhibited significantly lower fluorescence intensity. A rational for this unusual behaviour could not be found, unless the effect is related to the non-symmetric aromatic at the imidazole $(o$ substitution).

\section{Experimental}

\section{Materials and methods}

Synthesis grade chemicals and solvents of AR grade were obtained from various commercial sources and used without prior treatment. Reactions were monitored by TLC on pre-coated silica 60 aluminum sheets under UV light. Purification of the imidazolium compounds and their precursors applied simple extraction and crystallization. All products were analysed by NMR spectroscopy on $400 \mathrm{MHz}$ spectrometers from Jeol and Bruker. Product purities were confirmed by elemental analysis (CHN). IR spectra were recorded as ATR on a Perkin-Elmer spectrum 400 spectrophotometer. Melting points were determined using an Electrothermal melting point apparatus and are uncorrected. Fluorescence spectra were recorded on an Agilent Cary Eclipse spectrometer at $\mathrm{rt}$ in $1 \mathrm{~cm}$ quartz cuvettes.

\section{General procedure $\mathbf{A}(\mathbf{X}=\mathbf{C l})$}

A suspension of $3(1.6 \mathrm{mmol})$ in toluene $(20 \mathrm{~mL})$ was treated with 5 (1.8 mmol) and subsequently heated to reflux overnight. A greenish precipitate developed from the initial solution. After cooling, the solid was collected by filtration, washed with hexane $(20 \mathrm{~mL})$ and dried under vacuum to provide the imidazolium salt as greenish solid.

\section{General procedure $\mathbf{B}(\mathrm{X}=\mathrm{Br})$}

A solution of $6(0.25 \mathrm{mmol})$ and an alkyl or benzyl bromide $(0.75$ $\mathrm{mmol})$ in acetone or acetonitrile $(25 \mathrm{~mL})$ was refluxed for $12-$ $48 \mathrm{~h}$. The imidazolium salt gradually precipitated. The precipitate was filtered after cooling, washed with acetone $(2 \times 15 \mathrm{~mL})$ and dried to give a yellow solid in a yield of $80-95 \%$.

\section{9-(1-Imidazolyl) acridine (6a)}

The synthesis followed a modified approach of a previous report. ${ }^{42}$ A solution of $3 \mathrm{a}(1.0 \mathrm{~g}, 4.7 \mathrm{mmol})$ in toluene $(60 \mathrm{~mL})$ was treated with imidazole (369 $\mathrm{mg}, 5.4 \mathrm{mmol}$ ) and the reaction mixture was heated to reflux for $2 \mathrm{~d}$, when TLC indicated complete conversion. After cooling, the greenish solid was collected by filtration, washed with hexane $(3 \times 20 \mathrm{~mL})$, and dried under vacuum to provide $6 \mathbf{a}(930 \mathrm{mg}, 81 \%)$ as yellow powder. Mp 210-220 ${ }^{\circ} \mathrm{C}^{36}$

\section{6-Chloro-9-(1-imidazolyl)-2-methoxyacridine (6c)}

The synthesis followed a modified approach of a previous report. ${ }^{42}$ A solution of $3 \mathrm{c}$ (439 $\left.\mathrm{mg}, 1.6 \mathrm{mmol}\right)$ in toluene $(20 \mathrm{~mL})$ was treated with imidazole $(123 \mathrm{mg}, 1.8 \mathrm{mmol})$ and the reaction mixture was heated to reflux for $2 \mathrm{~d}$, when TLC indicated complete conversion. After cooling, the greenish solid was collected by filtration, washed with hexane $(20 \mathrm{~mL})$ and dried under vacuum to provide $6 \mathrm{c}$ (389 $\mathrm{mg}, 79 \%)$ as yellow powder. Mp 211-215 ${ }^{\circ} \mathrm{C} .{ }^{43}$

\section{1-(Acridin-9-yl)-3-hexylimidazolium chloride (7)}

1-Hexyl-imidazole (274 mg, $1.8 \mathrm{mmol}$ ) and 3a (337 mg, 1.6 $\mathrm{mmol}$ ) were reacted according to general method A to give 7 (430 mg, 75\%) as off-white solid. Mp 225-230 ${ }^{\circ} \mathrm{C}$. FTIR: $\nu_{\max }$ (ATR, $\left.\mathrm{cm}^{-1}\right)$ 3087, 2954, $2858(\mathrm{C}-\mathrm{H}), 1628(\mathrm{C}=\mathrm{N}), 1542,1446$, $1410(\mathrm{C}=\mathrm{C}), 1267,1135(\mathrm{C}-\mathrm{O}), 766(\mathrm{C}-\mathrm{Cl}) .{ }^{1} \mathrm{H}$ NMR $(400 \mathrm{MHz}$, DMSO-d $\left.{ }_{6}\right): \delta(\mathrm{ppm}) 9.99(\mathrm{~s}, 1 \mathrm{H}, \mathrm{NCHN}), 8.40(\mathrm{~d}, 2 \mathrm{H} J=8 \mathrm{~Hz})$, $8.37(\mathrm{~s}, 2 \mathrm{H}), 8.04(\mathrm{dt} \approx \mathrm{bt}, 2 \mathrm{H}, J=8 \mathrm{~Hz}), 7.80(\mathrm{dt} \approx \mathrm{bt}, 2 \mathrm{H}, J=9$ $\mathrm{Hz}), 7.67(\mathrm{dd} \approx \mathrm{bd}, 2 \mathrm{H}, J=9 \mathrm{~Hz}), 4.42\left(\mathrm{t}, 2 \mathrm{H}, \mathrm{NCH}_{2}\right) 2.01\left(\mathrm{~m}_{\mathrm{c}}\right.$, 2H, $\left.\mathrm{CH}_{2}\right), 1.41-1.31\left(\mathrm{~m}, 6 \mathrm{H}, \mathrm{CH}_{2}\right), 0.89$ (t, 3H, $\left.\mathrm{CH}_{3}\right) .{ }^{13} \mathrm{C} \mathrm{NMR}$ (100 MHz, DMSO-d $\left.{ }_{6}\right): \delta(\mathrm{ppm}) 149.10,139.21,132.10,130.03$, $129.55,125.94,124.38,122.55,122.14,118.79,50.35,31.12$, $29.37,25.83,22.45,14.37$. Anal. calcd for $\mathrm{C}_{22} \mathrm{H}_{24} \mathrm{ClN}_{3}$ : C 72.22, $\mathrm{H}$ 6.61, N 11.84\%; found: C 72.19, H 6.59, N 11.80\%. HRMS (ESI $\left.{ }^{+}\right)$ $m / z$ calcd for $\mathrm{C}_{22} \mathrm{H}_{24} \mathrm{~N}_{3}[\mathrm{M}-\mathrm{Cl}]^{+}: 330.1970(100 \%), 331.2004$ (24\%); found: 330.1999 (100\%), 331.2013 (38\%).

\section{1-(2-Methoxyacridin-9-yl)-3-methylimidazolium chloride (8)}

1-Methylimidazole (441 mg, $5.4 \mathrm{mmol}$ ) and $3 \mathbf{b}^{\mathbf{4 4}}$ (1.16 g, 4.8 $\mathrm{mmol}$ ) were reacted according to general method A to give $\mathbf{8}$ (1.15 g, 74\%) as greenish solid. Mp 210-215 ${ }^{\circ} \mathrm{C}$. FTIR: $\nu$ (ATR, $\left.\mathrm{cm}^{-1}\right)$ 3076, $2961(\mathrm{C}-\mathrm{H}), 1631(\mathrm{C}=\mathrm{N}), 1561,1477,1431$ $(\mathrm{C}=\mathrm{C}), 1226,1136,1023(\mathrm{C}-\mathrm{O}), 758(\mathrm{C}-\mathrm{Cl}) .{ }^{1} \mathrm{H}$ NMR $(400 \mathrm{MHz}$, DMSO-d $\left.{ }_{6}\right): \delta(\mathrm{ppm}) 9.82(\mathrm{~s}, 1 \mathrm{H}, \mathrm{NCHN}), 8.31(\mathrm{~d}, 1 \mathrm{H}, J=8 \mathrm{~Hz}$ ), 8.29-8.26 (m, 3H), $7.95\left(\mathrm{dt}, 1 \mathrm{H}, J_{\mathrm{t}}=9 \mathrm{~Hz}, J_{\mathrm{d}}=1 \mathrm{~Hz}\right), 7.75(\mathrm{dt}, 1 \mathrm{H}$, $\left.J_{\mathrm{t}}=9 \mathrm{~Hz}, J_{\mathrm{d}}=1 \mathrm{~Hz}\right), 7.70\left(\mathrm{dd}, 1 \mathrm{H}, J_{\mathrm{t}}=9 \mathrm{~Hz}, J_{\mathrm{d}}=3 \mathrm{~Hz}\right), 7.62(\mathrm{~d}$, $1 \mathrm{H}, J=8 \mathrm{~Hz}), 6.80(\mathrm{~d}, 1 \mathrm{H}, J=3 \mathrm{~Hz}), 4.12\left(\mathrm{~s}, 3 \mathrm{H}, \mathrm{NCH}_{3}\right), 3.90(\mathrm{~m}$, $\left.3 \mathrm{H}, \mathrm{OCH}_{3}\right) .{ }^{13} \mathrm{C}$ NMR (100 MHz, DMSO-d $\left.{ }_{6}\right): \delta$ (ppm) 159.44, 147.10 , 146.50, 139.79, 133.66, 132.01, 130.71, 129.97, 129.50, 126.93, 125.67, 125.18, 123.47, 122.57, 122.09, 98.15, 56.60, 37.21. Anal. calcd for $\mathrm{C}_{18} \mathrm{H}_{16} \mathrm{ClN}_{3} \mathrm{O}$ : C 66.36, $\mathrm{H} 4.59, \mathrm{~N} 12.90 \%$; found: $\mathrm{C}$ 66.31, $\mathrm{H} 4.55, \mathrm{~N} 12.92 \%$. HRMS (ESI ${ }^{+}$) $\mathrm{m} / \mathrm{z}$ calcd for $\mathrm{C}_{18} \mathrm{H}_{16} \mathrm{~N}_{3} \mathrm{O}[\mathrm{M}-\mathrm{Cl}]^{+}: 290.1293$ (100\%), 291.1327 (20\%); found: 290.1302 (100\%), 291.1325 (28\%).

\section{1-(2-Methoxyacridin-9-yl)-3-butylimidazolium chloride (9)}

1-Butylimidazole (448 $\mathrm{mg}, 3.6 \mathrm{mmol})$ and $3 \mathbf{b}^{\mathbf{4 4}}$ (770 $\mathrm{mg}, 3.2$ $\mathrm{mmol}$ ) were reacted according to general method A to give $\mathbf{9}$ (890 mg, 77\%) as greenish solid. Mp 212-220 ${ }^{\circ} \mathrm{C}$. FTIR: $\nu$ $\left(\mathrm{ATR}, \mathrm{cm}^{-1}\right)$ 3080, 2965, 2953, $2875(\mathrm{C}-\mathrm{H}), 1632(\mathrm{C}=\mathrm{N}), 1563$, 1478, 1435 (C=C), 1227, 1136, 1022 (C-O), 759 (C-Cl). ${ }^{1} \mathrm{H}$ NMR $\left(400 \mathrm{MHz}, \mathrm{DMSO}_{6}\right) \delta(\mathrm{ppm}) 9.92(\mathrm{~s}, 1 \mathrm{H}, \mathrm{NCHN}), 8.37(\mathrm{t}, 1 \mathrm{H}, J=$ $1 \mathrm{~Hz}), 8.34-8.30$ (m, 2H), 8.30 (d, 1H, J = 9 Hz), 7.95 (ddd, $1 \mathrm{H}, J$ $=8 / 7 / 1 \mathrm{~Hz}$ ), $7.78(\mathrm{ddd}, 1 \mathrm{H}, J=9 / 8 / 1 \mathrm{~Hz}), 7.74(\mathrm{dd}, 1 \mathrm{H}, J=9 / 3$ $\mathrm{Hz}), 7.59$ (bd, $1 \mathrm{H}, J=9 \mathrm{~Hz}), 6.70(\mathrm{~d}, 1 \mathrm{H}, J=3 \mathrm{~Hz}), 4.40(\mathrm{t}, 2 \mathrm{H}$, 
$\left.\mathrm{NCH}_{2}\right), 3.84\left(\mathrm{~s}, 3 \mathrm{H}, \mathrm{OCH}_{3}\right), 1.98\left(\mathrm{~m}, 2 \mathrm{H}, \mathrm{CH}_{2}\right), 1.37\left(\mathrm{~m}, 2 \mathrm{H}, \mathrm{CH}_{2}\right)$, $0.95\left(\mathrm{t}, 3 \mathrm{H}, \mathrm{CH}_{3}\right) .{ }^{13} \mathrm{C}$ NMR (100 MHz, DMSO-d 6 ): $\delta(\mathrm{ppm})$ 159.47, 147.13, 146.49, 139.23, 132.10, 130.77, 130.05, 129.65, 126.99, 125.62, 124.54, 123.39, 122.45, 121.94, 121.95, 97.79, 56.40, 50.05, 31.39, 19.49, 13.93. Anal. calcd for $\mathrm{C}_{21} \mathrm{H}_{22} \mathrm{ClN}_{3} \mathrm{O}: \mathrm{C}$ 68.56, H 6.03, N 11.42\%; found: C 68.62, H 6.08, N 11.32\%. HRMS $\left(\mathrm{ESI}^{+}\right.$) $\mathrm{m} / \mathrm{z}$ calcd for $\mathrm{C}_{21} \mathrm{H}_{22} \mathrm{~N}_{3} \mathrm{O}[\mathrm{M}-\mathrm{Cl}]^{+}: 332.1763$ (100\%), 333.1796 (23\%); found: 332.1790 (100\%), 333.1803 $(37 \%)$.

\section{1-(6-Chloro-2-methoxyacridin-9-yl)-3-methylimidazolium chloride (10)}

1-Methylimidazole (441 mg, $5.4 \mathrm{mmol}$ ) and 3c $(1.31 \mathrm{~g}, 4.7$ $\mathrm{mmol}$ ) were reacted according to general procedure A to give $\mathbf{1 0}$ (1.44 g, 85\%) as greenish solid. Mp 240-245 ${ }^{\circ} \mathrm{C}$. FTIR: $\nu$ $\left(\mathrm{ATR}, \mathrm{cm}^{-1}\right) 3053(\mathrm{C}-\mathrm{H}), 1631(\mathrm{C}=\mathrm{N}), 1564,1476,1423(\mathrm{C}=\mathrm{C})$, $1216(\mathrm{C}-\mathrm{O}), 832(\mathrm{C}-\mathrm{Cl}) .{ }^{1} \mathrm{H}$ NMR $\left(400 \mathrm{MHz}, \mathrm{DMSO}-\mathrm{d}_{6}\right): \delta(\mathrm{ppm})$ 9.77 (bs, $1 \mathrm{H}, \mathrm{NCHN}$ ), 8.35 (dd $\approx \mathrm{bd}, 2 \mathrm{H}, J=5 \mathrm{~Hz}$ ), 8.27 (bs, $1 \mathrm{H}$ ), $8.22(\mathrm{~d}, 1 \mathrm{H}, J=9 \mathrm{~Hz}), 7.75(\mathrm{dd}, 1 \mathrm{H}, J=9 / 3 \mathrm{~Hz}), 7.71-7.67(\mathrm{~m}$, $2 \mathrm{H}), 6.80(\mathrm{~d}, 1 \mathrm{H}, J=3 \mathrm{~Hz}), 4.07\left(\mathrm{~s}, 3 \mathrm{H}, \mathrm{NCH}_{3}\right), 3.86(\mathrm{~s}, 3 \mathrm{H}$, $\left.\mathrm{OCH}_{3}\right) \cdot{ }^{13} \mathrm{C}$ NMR (100 MHz, DMSO-d $): \delta(\mathrm{ppm})$ 159.67, 147.30, 146.93, 139.38, 135.93, 135.43, 134.17, 131.89, 129.98, 128.14, 127.66, 125.47, 124.59, 123.67, 121.24, 98.35, 56.69, 37.24. Anal. calcd for $\mathrm{C}_{18} \mathrm{H}_{15} \mathrm{Cl}_{2} \mathrm{~N}_{3} \mathrm{O}$ : C 60.01, $\mathrm{H} 4.20, \mathrm{~N} 11.66 \%$; found: $\mathrm{C}$ $59.98, \mathrm{H}$ 4.35, $\mathrm{N} 11.61 \%$. HRMS $\left(\mathrm{ESI}^{+}\right) \mathrm{m} / \mathrm{z}$ calcd for $\mathrm{C}_{18} \mathrm{H}_{15} \mathrm{ClN}_{3} \mathrm{O} \quad[\mathrm{M}-\mathrm{Cl}]^{+}: 324.0904$ (100\%), 325.0937 (20\%), 326.0875 (34\%), 327.0908 (7\%); found: 324.0898 (100\%), 325.0938 (35\%), 326.0886 (52\%), 327.0906 (10\%).

\section{1-(6-Chloro-2-methoxyacridin-9-yl)-3-ethylimidazolium chloride (11)}

1-Ethylimidazole (519 $\mathrm{mg}, 5.4 \mathrm{mmol})$ and $3 \mathrm{c}(1.3 \mathrm{~g}, 4.7 \mathrm{mmol})$ were reacted according to general method A to give 11 (1.41 g, 81\%) as greenish solid. Mp 214-216 ${ }^{\circ} \mathrm{C}$. FTIR: $\nu$ (ATR, $\mathrm{cm}^{-1}$ ) 3053, $2988(\mathrm{C}-\mathrm{H}), 1629(\mathrm{C}=\mathrm{N}), 1547,1432,1408(\mathrm{C}=\mathrm{C}), 1268$, $1140(\mathrm{C}-\mathrm{O}), 758(\mathrm{C}-\mathrm{Cl}) .{ }^{1} \mathrm{H}$ NMR $\left(400 \mathrm{MHz}, \mathrm{DMSO}-\mathrm{d}_{6}\right): \delta(\mathrm{ppm})$ 9.88 (s, 1H, NCHN), 8.35 (d, 2H, $=2 \mathrm{~Hz}$ ), 8.30 (bs, 1H), 8.27 (d, $2 \mathrm{H}, 10 \mathrm{~Hz}), 7.78-7.66(\mathrm{~m}, 3 \mathrm{H}), 6.73(\mathrm{~d}, 1 \mathrm{H}, 2 \mathrm{~Hz}), 4.42(\mathrm{t}, 2 \mathrm{H}$, $\left.\mathrm{NCH}_{2}\right), 3.86\left(\mathrm{~s}, 3 \mathrm{H}, \mathrm{OCH}_{3}\right), 1.60\left(\mathrm{t}, 3 \mathrm{H}, \mathrm{CH}_{3}\right) .{ }^{13} \mathrm{C} \mathrm{NMR}(100 \mathrm{MHz}$, DMSO-d $\left._{6}\right): \delta(\mathrm{ppm}) 159.69,147.32,146.98,138.98,135.46$, 134.72 , 131.94, 130.07, 128.18, 127.66, 125.40, 124.66, 124.33, 123.63, 121.19, 98.36, 56.62, 45.80, 15.02. Anal. calcd for $\mathrm{C}_{19} \mathrm{H}_{17} \mathrm{Cl}_{2} \mathrm{~N}_{3} \mathrm{O}$ : C 60.97, $\mathrm{H}$ 4.58, N 11.23\%; found: $\mathrm{C} 60.93, \mathrm{H}$ 4.55, N 11.30\%. HRMS (ESI ${ }^{+}$) $m / z$ calcd for $\mathrm{C}_{19} \mathrm{H}_{17} \mathrm{ClN}_{3} \mathrm{O}[\mathrm{M}-$ $\mathrm{Cl}]^{+}: 338.1060$ (100\%), 339.1094 (21\%), 340.1031 (34\%), 341.1065 (7\%); found: 338.1064 (100\%), 339.1095 (44\%), 340.1045 (56\%), 341.1062 (10\%).

\section{1-(6-Chloro-2-methoxyacridin-9-yl)-3-butylimidazolium chloride (12)}

1-Butylimidazole (672 mg, $5.4 \mathrm{mmol})$ and 3c (1.3 g, $4.7 \mathrm{mmol})$ were reacted according to general method A to give $12(1.52 \mathrm{~g}$, 80\%) as greenish solid. Mp 220-225 ${ }^{\circ} \mathrm{C}$. FTIR: $\nu$ (ATR, $\mathrm{cm}^{-1}$ ) 3079, $2956(\mathrm{C}-\mathrm{H}), 1631(\mathrm{C}=\mathrm{N})$, 1542, 1480, $1426(\mathrm{C}=\mathrm{C}), 1238$, 1127 (C-O), 830 (C-Cl). ${ }^{1} \mathrm{H}$ NMR (400 MHz, DMSO-d $\left.{ }_{6}\right): \delta(\mathrm{ppm})$ 10.00 (s, 1H, NCHN), 8.42 (bs, 1H), 8.38 (d, 1H, $J=2 \mathrm{~Hz}$ ), 8.33 (d,
$1 \mathrm{H}, J=1 \mathrm{~Hz}), 8.25$ (d, $1 \mathrm{H}, J=9 \mathrm{~Hz}), 7.80(\mathrm{dd}, 1 \mathrm{H}, J=10 / 2 \mathrm{~Hz})$, $7.75(\mathrm{dd}, 1 \mathrm{H}, J=10 / 3 \mathrm{~Hz}), 7.68(\mathrm{~d}, 1 \mathrm{H}, J=9 \mathrm{~Hz}), 6.69$ (d, 1H, $J=$ $3 \mathrm{~Hz}), 4.46$ (t, $\left.2 \mathrm{H}, \mathrm{NCH}_{2}\right), 3.89\left(\mathrm{~s}, 3 \mathrm{H}, \mathrm{OCH}_{3}\right), 2.02\left(\mathrm{~m}, 2 \mathrm{H}, \mathrm{CH}_{2}\right)$, $1.42\left(\mathrm{~m}, 2 \mathrm{H}, \mathrm{CH}_{2}\right), 0.99\left(\mathrm{t}, 3 \mathrm{H}, \mathrm{CH}_{3}\right) .{ }^{13} \mathrm{C}$ NMR (100 MHz, DMSO$\left.\mathrm{d}_{6}\right): \delta(\mathrm{ppm}) 159.47,147.30,146.99,139.23,135.49,134.10$, 131.99, 130.15, 128.23, 127.71, 125.59, 124.59, 124.49, 123.60, 121.13 , 98.00, 56.48, 50.10, 31.36, 19.50, 13.92. Anal. calcd for $\mathrm{C}_{21} \mathrm{H}_{21} \mathrm{Cl}_{2} \mathrm{~N}_{3} \mathrm{O}$ : C 62.69, H 5.26, N 10.44\%; found: $\mathrm{C} 62.51, \mathrm{H}$ 5.25, N 10.31\%. HRMS (ESI ${ }^{+}$) $m / z$ calcd for $\mathrm{C}_{21} \mathrm{H}_{21} \mathrm{ClN}_{3} \mathrm{O}[\mathrm{M}-$ $\mathrm{Cl}]^{+}: \quad 366.1373$ (100\%), 367.1407 (23\%), 368.1344 (35\%), 369.1378 (8\%); found: 366.1418 (100\%), 367.1409 (53\%), 368.1361 (66\%), 369.1374 (19\%).

\section{1-(6-Chloro-2-methoxyacridin-9-yl)-3-octylimidazolium chloride (13)}

1-Octylimidazole (324 mg, $1.8 \mathrm{mmol})$ and 3c (439 mg, $1.6 \mathrm{mmol})$ were reacted according to general method A to give $13(545 \mathrm{mg}$, 75\%) as yellow solid. Mp 320-330 ${ }^{\circ}$ C. FTIR: $\nu\left(A T R, \mathrm{~cm}^{-1}\right.$ ) 3069, 2954, 2924, $2854(\mathrm{C}-\mathrm{H}), 1631(\mathrm{C}=\mathrm{N})$, 1595, 1561, $1476(\mathrm{C}=\mathrm{C})$, 1281, 1233, 1154, 1030 (C-O), 818, 747 (C-Cl). ${ }^{1} \mathrm{H}$ NMR (400 MHz, DMSO-d $\left.\mathrm{d}_{6}\right): \delta(\mathrm{ppm}) 9.86(\mathrm{~s}, 1 \mathrm{H}, \mathrm{NCHN}), 8.33$ (bs, 1H), 8.31 $(\mathrm{s}, 1 \mathrm{H}), 8.28(\mathrm{~d}, 1 \mathrm{H}, J=10 \mathrm{~Hz}), 7.95\left(\mathrm{dt}, 1 \mathrm{H}, J_{\mathrm{t}}=7 \mathrm{~Hz}, J_{\mathrm{d}}=2 \mathrm{~Hz}\right)$, $7.77\left(\mathrm{dt}, 1 \mathrm{H}, J_{\mathrm{t}}=7 \mathrm{~Hz}, J_{\mathrm{d}}=1 \mathrm{~Hz}\right), 7.71(\mathrm{dd}, 1 \mathrm{H}, J=9 / 3 \mathrm{~Hz}), 7.56$ $(\mathrm{d}, 1 \mathrm{H}, J=9 \mathrm{~Hz}), 6.69$ (d, $1 \mathrm{H}, J=3 \mathrm{~Hz}), 4.42\left(\mathrm{t}, 2 \mathrm{H}, \mathrm{NCH}_{2}\right), 3.87$ (s, 3H, $\left.\mathrm{OCH}_{3}\right), 2.00\left(\mathrm{~m}, 2 \mathrm{H}, \mathrm{CH}_{2}\right), 1.36-1.26\left(\mathrm{~m}, 10 \mathrm{H}, \mathrm{CH}_{2}\right), 0.85$ $\left(\mathrm{t}, 3 \mathrm{H}, \mathrm{CH}_{3}\right) \cdot{ }^{13} \mathrm{C}$ NMR (100 MHz, DMSO-d $\left.\mathrm{d}_{6}\right): \delta(\mathrm{ppm})$ 159.47, 147.14, 146.50, 139.22, 133.58, 132.11, 130.76, 130.08, 129.61, $126.96,125.62,124.53,123.40,122.47,121.91,97.86,56.39$, $50.32,31.70,29.39,29.07,28.91,26.15,22.62,14.49$. Anal. calcd for $\mathrm{C}_{25} \mathrm{H}_{29} \mathrm{Cl}_{2} \mathrm{~N}_{3} \mathrm{O}$ : C 65.50, $\mathrm{H}$ 6.38, $\mathrm{N} 9.17 \%$; found: $\mathrm{C} 65.52, \mathrm{H}$ 6.35, N 9.19\%. HRMS $\left(\mathrm{ESI}^{+}\right) \mathrm{m} / \mathrm{z}$ calcd for $\mathrm{C}_{25} \mathrm{H}_{29} \mathrm{ClN}_{3} \mathrm{O}[\mathrm{M}-$ $\mathrm{Cl}]^{+}: 422.1999$ (100\%), 423.2033 (28\%), 424.1970 (34\%), 425.2004 (10\%); found: 422.1992 (100\%), 423.2543 (\%), $424.1968(46 \%)$.

\section{1-(Acridin-9-yl)-3-(4-methylbenzyl)-imidazolium chloride (14)}

1-(4-Methylbenzyl)-imidazole (310 $\mathrm{mg}, 1.8 \mathrm{mmol})$ and $\mathbf{3 a}$ (337 mg, $1.6 \mathrm{mmol}$ ) were reacted according to general method A to give $14(520 \mathrm{mg}, 85 \%)$ as white solid. Mp 205-210 ${ }^{\circ} \mathrm{C}$. FTIR: $\nu$ $\left(\mathrm{ATR}, \mathrm{cm}^{-1}\right)$ 3020, $2946(\mathrm{C}-\mathrm{H}), 1626(\mathrm{C}=\mathrm{N}), 1536,1520,1439$ $(\mathrm{C}=\mathrm{C}), 1259,1132(\mathrm{C}-\mathrm{C}), 770(\mathrm{C}-\mathrm{Cl}) .{ }^{1} \mathrm{H}$ NMR (400 MHz, DMSO$\left.\mathrm{d}_{6}\right): \delta(\mathrm{ppm}) 9.95(\mathrm{~s}, 1 \mathrm{H}, \mathrm{NCHN}), 8.34-8.28(\mathrm{~m}, 4 \mathrm{H}), 7.99(\mathrm{bt}, 2 \mathrm{H}$, $J=8 \mathrm{~Hz}), 7.77\left(\mathrm{dt}, 2 \mathrm{H}, J_{\mathrm{t}}=6 \mathrm{~Hz}, J_{\mathrm{d}}=1 \mathrm{~Hz}\right), 7.60(\mathrm{~d}, 2 \mathrm{H}, J=9 \mathrm{~Hz})$, $7.48(\mathrm{~d}, 2 \mathrm{H}, J=8 \mathrm{~Hz}), 7.27(\mathrm{~d}, 2 \mathrm{H}, J=8 \mathrm{~Hz}), 5.59(\mathrm{~s}, 2 \mathrm{H}), 2.30(\mathrm{~s}$, $\left.\mathrm{CH}_{3}\right) \cdot{ }^{13} \mathrm{C}$ NMR (100 MHz, DMSO-d $\left.{ }_{6}\right): \delta(\mathrm{ppm})$ 149.06, 139.46, 139.04, 136.02, 132.05, 131.65, 130.25, 130.01, 129.57, 129.39, $126.18,124.39,122.51,122.08,53.26,21.32$. Anal. calcd for $\mathrm{C}_{24} \mathrm{H}_{20} \mathrm{ClN}_{3}$ : C 74.70, H 5.22, N 10.89\%; found: C $74.80, \mathrm{H}$ 5.20, N 10.90\%. HRMS (ESI $\left.{ }^{+}\right) \mathrm{m} / z$ calcd for $\mathrm{C}_{24} \mathrm{H}_{20} \mathrm{~N}_{3}[\mathrm{M}-\mathrm{Cl}]^{+}$: 350.1657 (100\%), 351.1691 (27\%); found: 350.1650 (100\%), $351.1682(74 \%)$.

\section{1-(Acridin-9-yl)-3-(4-bromobenzyl)-imidazolium bromide (15)}

4-Bromobenzyl bromide (748 mg, $3.0 \mathrm{mmol}$ ) and 6a (244 mg, 1.0 $\mathrm{mmol}$ ) were reacted according to general method $\mathrm{B}$ to give $\mathbf{1 5}$ (445 mg, 90\%) as yellow solid. Mp 280-290 ${ }^{\circ} \mathrm{C}$. FTIR: $\nu$ 
(ATR, $\left.\mathrm{cm}^{-1}\right)$ 3010, $2950(\mathrm{C}-\mathrm{H}), 1633(\mathrm{C}=\mathrm{N}), 1534,1425(\mathrm{C}=\mathrm{C})$, 1137, 1030 (C-O), 750 (C-Br). ${ }^{1} \mathrm{H}$ NMR (400 MHz, DMSO-d 6 ): $\delta(\mathrm{ppm}) 9.93(\mathrm{~s}, 1 \mathrm{H}, \mathrm{NCHN}), 8.39-8.35(\mathrm{~m}, 3 \mathrm{H}), 8.33(\mathrm{t}, 1 \mathrm{H}, J=2$ $\mathrm{Hz}), 8.03\left(\mathrm{dt}, 2 \mathrm{H}, J_{\mathrm{t}}=7 \mathrm{~Hz}, J_{\mathrm{d}}=1 \mathrm{~Hz}\right), 7.81\left(\mathrm{dt}, 2 \mathrm{H}, J_{\mathrm{t}}=6 \mathrm{~Hz}, J_{\mathrm{d}}=\right.$ $1 \mathrm{~Hz}), 7.72(\mathrm{~d}, 2 \mathrm{H}, J=8 \mathrm{~Hz}), 7.68(\mathrm{~d}, 2 \mathrm{H}, J=8 \mathrm{~Hz}), 7.60(\mathrm{~d}, 2 \mathrm{H}, J$ $=8 \mathrm{~Hz}), 5.67\left(\mathrm{~s}, 2 \mathrm{H}, \mathrm{NCH}_{2}\right) \cdot{ }^{13} \mathrm{C} \mathrm{NMR}\left(100 \mathrm{MHz}, \mathrm{DMSO}_{6}\right)$ : $\delta(\mathrm{ppm}) 149.05,139.59,135.98,133.88,132.62,132.07,131.77$, 129.98, 129.57, 126.23, 124.47, 123.01, 122.60, 122.06, 52.76. Anal. calcd for $\mathrm{C}_{23} \mathrm{H}_{17} \mathrm{Br}_{2} \mathrm{~N}_{3}$ : C 55.78, $\mathrm{H} 3.46, \mathrm{~N} 8.49 \%$; found: $\mathrm{C}$ 55.77, $\mathrm{H} 3.47, \mathrm{~N} 8.51 \%$. HRMS $\left(\mathrm{ESI}^{+}\right) \mathrm{m} / z$ calcd for $\mathrm{C}_{23} \mathrm{H}_{17} \mathrm{BrN}_{3}$ $[\mathrm{M}-\mathrm{Br}]^{+}: 414.0606$ (100\%), 415.0639 (26\%), 426.0605 (100\%), 417.0638 (26\%); found: 414.0626 (100\%), 415.0641 (35\%), 416.0608 (99\%), 417.0621 (35\%).

\section{1-(Acridin-9-yl)-3-(2-bromobenzyl)-imidazolium bromide (16)}

2-Bromobenzyl bromide (748 mg, $3.0 \mathrm{mmol}$ ) and 6a (244 mg, 1.0 $\mathrm{mmol}$ ) were reacted according to general method $\mathrm{B}$ to give $\mathbf{1 6}$ (449 mg, 91\%) as yellow solid. Mp 276-278 ${ }^{\circ} \mathrm{C}$. FTIR: $\nu$ (ATR, $\mathrm{cm}^{-1}$ ) 3023, $2960(\mathrm{C}-\mathrm{H}), 1632(\mathrm{C}=\mathrm{N}), 1518,1423(\mathrm{C}=\mathrm{C})$, 1269, 1135 (C-O), 750, 806 (C-Br). ${ }^{1} \mathrm{H}$ NMR (400 MHz, DMSO$\left.\mathrm{d}_{6}\right): \delta(\mathrm{ppm}) 9.93(\mathrm{~s}, 1 \mathrm{H}, \mathrm{NCHN}), 8.43(\mathrm{t}, 1 \mathrm{H}, J=2 \mathrm{~Hz}), 8.38(\mathrm{bd}$, $2 \mathrm{H}, J=10 \mathrm{~Hz}), 8.32(\mathrm{t}, 1 \mathrm{H}, J=2 \mathrm{~Hz}), 8.04\left(\mathrm{dt}, J_{\mathrm{t}}=6 \mathrm{~Hz}, J_{\mathrm{d}}=1\right.$ $\mathrm{Hz}$ ), $7.84-7.80(\mathrm{~m}, 3 \mathrm{H}), 7.70(\mathrm{dd} \approx \mathrm{bd}, 1 \mathrm{H}, J=8 \mathrm{~Hz}$ ), 7.67 (bd, $2 \mathrm{H}, J=8 \mathrm{~Hz}), 7.57\left(\mathrm{dt}, 1 \mathrm{H}, J_{\mathrm{t}}=7 \mathrm{~Hz}, J_{\mathrm{d}}=2 \mathrm{~Hz}\right), 7.45\left(\mathrm{dt}, J_{\mathrm{t}}=\right.$ $7 \mathrm{~Hz}, J_{\mathrm{d}}=2 \mathrm{~Hz}$ ), $5.77\left(\mathrm{~s}, 2 \mathrm{H}, \mathrm{NCH}_{2}\right) .{ }^{13} \mathrm{C}$ NMR (100 MHz, DMSO$\left.\mathrm{d}_{6}\right): \delta(\mathrm{ppm}) 149.08,140.18,135.93,133.93,133.30,132.40$, 132.08, 130.05, 129.60, 129.25, 126.35, 124.69, 124.14, 122.45, 122.15, 100.00, 53.97. Anal. calcd for $\mathrm{C}_{23} \mathrm{H}_{17} \mathrm{Br}_{2} \mathrm{~N}_{3}$ : C 55.78, $\mathrm{H}$ 3.46, N 8.49\%; found: C 55.79, H 3.49, N 8.52\%. HRMS (ESI $\left.{ }^{+}\right) \mathrm{m} /$ $z$ calcd for $\mathrm{C}_{23} \mathrm{H}_{17} \mathrm{BrN}_{3}[\mathrm{M}-\mathrm{Br}]^{+}: 414.0606$ (100\%), 415.0639 (26\%), 426.0605 (100\%), 417.0638 (26\%); found: 414.0621 (100\%), 415.0642 (32\%), 416.0603 (98\%), 417.0622 (32\%).

\section{1-(Acridin-9-yl)-3-(4-nitrobenzyl)-imidazolium bromide (17)}

4-Nitrobenzyl bromide (486 mg, $2.3 \mathrm{mmol}$ ) and 6a (183 mg, 0.75 $\mathrm{mmol}$ ) were reacted according to general method $\mathrm{B}$ to give $\mathbf{1 7}$ (315 mg, 91\%) as yellow solid. Mp 220-230 ${ }^{\circ} \mathrm{C}$. FTIR: $\nu$ (ATR, $\mathrm{cm}^{-1}$ ) 3064, $2928(\mathrm{C}-\mathrm{H}), 1605(\mathrm{C}=\mathrm{N})$, 1542, 1513, 1428, $1349(\mathrm{C}=\mathrm{C}), 1271,1140(\mathrm{C}-\mathrm{O}), 757(\mathrm{C}-\mathrm{Br}) .{ }^{1} \mathrm{H}$ NMR $(400 \mathrm{MHz}$, DMSO-d $\left.{ }_{6}\right): \delta(\mathrm{ppm}) 9.97(\mathrm{~s}, 1 \mathrm{H}, \mathrm{NCHN}), 8.44-8.35(\mathrm{~m}, 6 \mathrm{H}), 8.04$ (bt, $2 \mathrm{H}, J=8 \mathrm{~Hz}), 7.89(\mathrm{~d}, 2 \mathrm{H}, J=8 \mathrm{~Hz}), 7.82(\mathrm{t}, 2 \mathrm{H}, J=8 \mathrm{~Hz})$, $7.72(\mathrm{~d}, 2 \mathrm{H}, J=8 \mathrm{~Hz}), 5.85\left(\mathrm{~s}, 2 \mathrm{H}, \mathrm{NCH}_{2}\right) .{ }^{13} \mathrm{C} \mathrm{NMR}(100 \mathrm{MHz}$, DMSO-d $\left.{ }_{6}\right): \delta$ (ppm) 149.08, 148.33, 141.87, 140.00, 135.95, 132.08, 130.64, 130.01, 129.58, 126.39, 124.70, 122.67, 122.05, 52.59. Anal. calcd for $\mathrm{C}_{23} \mathrm{H}_{17} \mathrm{BrN}_{4} \mathrm{O}_{2}$ : C 59.88, H 3.71, N 12.15; found: C 59.90, H 3.79, N 12.20\%. HRMS (ESI ${ }^{+}$) $\mathrm{m} / z$ calcd for $\mathrm{C}_{23} \mathrm{H}_{17} \mathrm{~N}_{4} \mathrm{O}_{2}[\mathrm{M}-\mathrm{Br}]^{+}: 381.1352$ (100\%), 382.1385 (25\%); found 381.1383 (100\%), 382.1393 (40\%).

\section{1-(Acridin-9-yl)-3-(phenacyl)-imidazolium bromide (18)}

2-Bromo-acetophenone (596 mg, $3.0 \mathrm{mmol}$ ) and 6a (244 mg, 1.0 $\mathrm{mmol}$ ) were reacted according to general method $\mathrm{B}$ to give 18 (401 mg, 91\%) as yellow solid. Mp 190-200 ${ }^{\circ} \mathrm{C}$. FTIR: $\nu$ (ATR, $\mathrm{cm}^{-1}$ ) 3064, $2928(\mathrm{C}-\mathrm{H}), 1689(\mathrm{C}=\mathrm{O}), 1633(\mathrm{C}=\mathrm{N}), 1540$, 1426, 1424, 1347 (C=C), 1224, 1146 (C-O), 752 (C-Br). ${ }^{1} \mathrm{H}$ NMR $\left(\mathrm{DMSO}_{\mathrm{d}}\right): \delta(\mathrm{ppm}) 9.82(\mathrm{~s}, 1 \mathrm{H}, \mathrm{NCHN}), 8.44(\mathrm{dd} \approx \mathrm{bs}, 1 \mathrm{H}), 8.41$ $(\mathrm{d}, 2 \mathrm{H}, J=8 \mathrm{~Hz}), 8.25(\mathrm{t}, 1 \mathrm{H}, J=3 \mathrm{~Hz}), 8.16(\mathrm{~d}, 2 \mathrm{H}, J=8 \mathrm{~Hz}), 8.06$ $\left(\mathrm{dt}, 2 \mathrm{H}, J_{\mathrm{t}}=9 \mathrm{~Hz}, J_{\mathrm{d}}=1 \mathrm{~Hz}\right), 7.88(\mathrm{bd}, 2 \mathrm{H}, J=9 \mathrm{~Hz}), 7.82(\mathrm{t}, 1 \mathrm{H}, J$ $=7 \mathrm{~Hz}), 7.71-7.67(\mathrm{~m}, 4 \mathrm{H}), 6.32(\mathrm{~s}, 2 \mathrm{H}) .{ }^{13} \mathrm{C}$ NMR $\left(\right.$ DMSO-d $\left._{6}\right)$ : $\delta(\mathrm{ppm}) 191.73,149.06,140.96,135.98,135.22,134.09,132.04$, 130.07, 129.68, 129.64, 128.83, 125.81, 125.52, 122.17, 122.14, 56.65. Anal. calcd for $\mathrm{C}_{24} \mathrm{H}_{18} \mathrm{BrN}_{3} \mathrm{O}$ : C 64.88, $\mathrm{H}$ 4.08, N 9.46\%; found: $\mathrm{C}$ 64.86, $\mathrm{H}$ 4.05, $\mathrm{N}$ 9.51\%. HRMS $\left(\mathrm{ESI}^{+}\right) \mathrm{m} / \mathrm{z}$ calcd for $\mathrm{C}_{24} \mathrm{H}_{18} \mathrm{~N}_{3} \mathrm{O}[\mathrm{M}-\mathrm{Br}]^{+}: 364.1450$ (100\%), 365.1483 (27\%); found: 364.1433 (100\%), 265.1463 (36\%).

\section{1-(Acridin-9-yl)-3-(4-bromophenacyl)-imidazolium bromide} (19)

2,4'-Dibromo-acetophenone (624 $\mathrm{mg}, 2.2 \mathrm{mmol}$ ) and $6 \mathbf{6}$ (183 mg, $0.75 \mathrm{mmol}$ ) were reacted according to general method B to give 19 (372 mg, 95\%) as colourless solid. Mp 220-230 ${ }^{\circ} \mathrm{C}$. FTIR: $\nu$ (ATR, $\left.\mathrm{cm}^{-1}\right)$ 3081, $2966(\mathrm{C}-\mathrm{H}), 1698(\mathrm{C}=\mathrm{N}), 1585,1423$, 1393 (C=C), 1269, 1135 (C-O), 987, 749 (C-Br). ${ }^{1} \mathrm{H}$ NMR (DMSO$\left.\mathrm{d}_{6}\right): \delta(\mathrm{ppm}) 9.81(\mathrm{t} \approx \mathrm{bs}, 1 \mathrm{H}, \mathrm{NCHN}), 8.44(\mathrm{~d}, 1 \mathrm{H}, J=2 \mathrm{~Hz}), 8.41$ $(\mathrm{bd}, 2 \mathrm{H}, J=8 \mathrm{~Hz}), 8.24(\mathrm{t}, 1 \mathrm{H}, J=2 \mathrm{~Hz}), 8.09(\mathrm{~d}, 2 \mathrm{H}, J=8 \mathrm{~Hz})$, 8.08-8.06 (m, 2H), $7.92(\mathrm{~d}, 2 \mathrm{H}, J=8 \mathrm{~Hz}), 7.91-7.86(\mathrm{~m}, 2 \mathrm{H}), 7.68$ (d, $2 \mathrm{H}, J=8 \mathrm{~Hz}), 6.29\left(\mathrm{~s}, 2 \mathrm{H}, \mathrm{NCH}_{2}\right) .{ }^{13} \mathrm{C}$ NMR (DMSO-d 6 ): $\delta(\mathrm{ppm}) 191.22,149.12,140.99,136.05,133.23,132.84,132.10$, 130.84, 130.13, 129.68, 129.40, 125.85, 125.60, 122.22, 56.65. Anal. calcd for $\mathrm{C}_{24} \mathrm{H}_{17} \mathrm{Br}_{2} \mathrm{~N}_{3} \mathrm{O}$ : C 55.09, $\mathrm{H} 3.27, \mathrm{~N} 8.03$; found: $\mathrm{C}$ 55.07, H 3.30, N 8.05\%. HRMS $\left(\mathrm{ESI}^{+}\right.$) $\mathrm{m} / z$ calcd for $\mathrm{C}_{24} \mathrm{H}_{17} \mathrm{BrN}_{3} \mathrm{O}$ $[\mathrm{M}-\mathrm{Br}]^{+}: 442.0555$ (100\%), 443.0589 (27\%), 444.0535 (98\%), 445.0569 (26\%); found 442.1206 (100\%), 443.1237 (27\%), 444.1186 (31\%), 445.1207 (10\%).

\section{1-(6-Chloro-2-methoxyacridin-9-yl)-3-benzylimidazolium chloride (20)}

1-Benzylimidazole (570 mg, $3.6 \mathrm{mmol})$ and $3 \mathrm{c}(878 \mathrm{mg}, 3.2$ $\mathrm{mmol}$ ) were reacted according to general method A to give 20 (1.1 g, 80\%) as greenish solid. Mp 245-250 ${ }^{\circ} \mathrm{C}$. FTIR: $\nu$ $\left(\mathrm{ATR}, \mathrm{cm}^{-1}\right) 2960(\mathrm{C}-\mathrm{H}), 1627(\mathrm{C}=\mathrm{N}), 1556,1440,1409(\mathrm{C}=\mathrm{C})$, 1141, 1030 (C-O), 763 (C-Br). ${ }^{1} \mathrm{H}$ NMR (DMSO-d 6 ): $\delta$ (ppm) 9.92 $(\mathrm{s}, 1 \mathrm{H}, \mathrm{NCHN}), 8.43(\mathrm{~d}, 1 \mathrm{H}, J=2 \mathrm{~Hz}), 8.35(\mathrm{~d}, 2 \mathrm{H}, J=1 \mathrm{~Hz}), 8.27$ $(\mathrm{d}, 1 \mathrm{H}, J=10 \mathrm{~Hz}), 7.82(\mathrm{dd}, 1 \mathrm{H}, J=10 / 2 \mathrm{~Hz}), 7.74(\mathrm{dd}, 1 \mathrm{H}, J=10 /$ $3 \mathrm{~Hz}$ ), 7.68 (d, 1H, $J=10 \mathrm{~Hz}$ ), 7.60 (d, 2H, $=7 \mathrm{~Hz}), 7.53-7.46$ $(\mathrm{m}, 3 \mathrm{H}), 6.58$ (d, $1 \mathrm{H}, J=3 \mathrm{~Hz}$ ), 5.72-5.63 (AB-syst., $2 \mathrm{H}, \mathrm{NCH}_{2}$ ), $3.83\left(\mathrm{~s}, 3 \mathrm{H}, \mathrm{OCH}_{3}\right) \cdot{ }^{13} \mathrm{C}$ NMR $\left(\mathrm{DMSO}_{6}\right): \delta(\mathrm{ppm}) 159.70,147.26$, 146.98, 139.61, 135.48, 134.98, 134.09, 131.99, 130.15, 129.70, 129.53, 129.10, 128.22, 127.69, 125.90, 124.75, 124.46, 123.56, 121.02, 97.76, 56.38, 53.41. Anal. calcd for $\mathrm{C}_{24} \mathrm{H}_{19} \mathrm{Cl}_{2} \mathrm{~N}_{3} \mathrm{O}: \mathrm{C}$ 66.06. H 4.39, N 9.63\%; found: C 66.09, H 4.41, N 9.60\%. HRMS $\left(\mathrm{ESI}^{+}\right) \mathrm{m} / z$ calcd for $\mathrm{C}_{24} \mathrm{H}_{19} \mathrm{ClN}_{3} \mathrm{O}[\mathrm{M}-\mathrm{Cl}]^{+}: 400.1217(100 \%)$, 401.1250 (27\%), 402.1188 (35\%), 403.1221 (8\%); found: 400.1214 (100\%), 401.1241 (27\%), 402.1189 (33\%), 403.1215 (8\%).

1-(6-Chloro-2-methoxyacridin-9-yl)-3-(phenacyl) imidazolium bromide (21)

2-Bromoacetophenone (298 mg, $1.5 \mathrm{mmol}$ ) and 6c (154 mg, 0.50 mmol) were reacted according to general method $\mathrm{B}$ to give 21 (227 $\mathrm{mg}, 90 \%$ ) as yellow solid. Mp 250-260 ${ }^{\circ} \mathrm{C}$. FTIR: $\nu$ $\left(\mathrm{ATR}, \mathrm{cm}^{-1}\right)$ 3064, $2996(\mathrm{C}-\mathrm{H}), 1683(\mathrm{C}=\mathrm{O}), 1633(\mathrm{C}=\mathrm{N}), 1562$, 
1477, $1424(\mathrm{C}=\mathrm{C}), 1234,1074(\mathrm{C}-\mathrm{O}), 757(\mathrm{C}-\mathrm{Br}) .{ }^{1} \mathrm{H}$ NMR $\left(\mathrm{DMSO}_{6}\right): \delta(\mathrm{ppm}) 9.81(\mathrm{~s}, 1 \mathrm{H}, \mathrm{NCHN}), 8.43(\mathrm{dd} \approx \mathrm{bd}, 1 \mathrm{H}, J=2$ $\mathrm{Hz}), 8.39(\mathrm{t}, 1 \mathrm{H}, J=1 \mathrm{~Hz}), 8.28(\mathrm{~d}, 1, J=10 \mathrm{~Hz}), 8.25(\mathrm{t}, 1 \mathrm{H}, J=3$ $\mathrm{Hz}), 8.16(\mathrm{dd}, 2 \mathrm{H}, J=8 / 1 \mathrm{~Hz}), 7.87(\mathrm{dd}, 1 \mathrm{H}, J=9 / 2 \mathrm{~Hz}), 7.82(\mathrm{tt}$, $1 \mathrm{H}, J=8 / 1 \mathrm{~Hz}), 7.76(\mathrm{dd}, 1 \mathrm{H}, J=8 / 3 \mathrm{~Hz}), 7.73(\mathrm{~d}, 1 \mathrm{H}, J=10 \mathrm{~Hz})$, $7.69(\mathrm{t}, 2 \mathrm{H}, J=8 \mathrm{~Hz}), 6.78$ (d, $1 \mathrm{H}, J=2 \mathrm{~Hz}$ ), 6.41-6.26 (AB-syst., $\left.2 \mathrm{H}, \mathrm{NCH}_{2}\right), 3.98\left(\mathrm{~s}, 3 \mathrm{H}, \mathrm{OCH}_{3}\right) \cdot{ }^{13} \mathrm{C} \mathrm{NMR}\left(\mathrm{DMSO}_{6}\right): \delta(\mathrm{ppm})$ 191.97, 159.91, 147.29, 147.0, 141.23, 135.51, 135.32, 134.09, 132.02, 130.23, 129.75, 128.90, 128.29, 127.78, 126.03, 125.21, 124.21, 123.86, 121.10, 100.01, 97.56, 56.76, 56.54. Anal. calcd for $\mathrm{C}_{25} \mathrm{H}_{19} \mathrm{BrClN}_{3} \mathrm{O}_{2}$ : C 59.02, H 3.76, N 8.26\%; found: C 59.21, $\mathrm{H}$ 3.78, N 8.31\%. HRMS (ESI $\left.{ }^{+}\right) m / z$ calcd for $\mathrm{C}_{25} \mathrm{H}_{19} \mathrm{ClN}_{3} \mathrm{O}_{2}[\mathrm{M}-$ $\mathrm{Br}]^{+}: \quad 428.1166$ (100\%), 429.1199 (28\%), 430.1137 (34\%), 431.1170 (10\%); found: 428.1194 (100\%), 429.1207 (39\%), 430.1157 (45\%), 431.1178 (13\%).

\section{1-(6-Chloro-2-methoxyacridin-9-yl)-3-(4-bromophenacyl)-} imidazolium bromide (22)

$2,4^{\prime}$-Dibromoacetophenone (624 mg, $\left.2.2 \mathrm{mmol}\right)$ and $6 \mathrm{c}(231 \mathrm{mg}$, $0.83 \mathrm{mmol}$ ) were reacted according to general method $\mathrm{B}$ to give 22 (414 mg, 85\%) as yellow solid. Mp 260-270 ${ }^{\circ}$ C. FTIR: $\nu$ $\left(\mathrm{ATR}, \mathrm{cm}^{-1}\right)$ 3072, $2983(\mathrm{C}-\mathrm{H}), 1693(\mathrm{C}=\mathrm{N}), 1634,1584,1477$ $(\mathrm{C}=\mathrm{C}), 1425,1235,1067$ (C-O), $812(\mathrm{C}-\mathrm{Br}) .{ }^{1} \mathrm{H}$ NMR (DMSO-d 6 ): $\delta(\mathrm{ppm}) 9.78(\mathrm{~s}, 1 \mathrm{H}, \mathrm{NCHN}), 8.44(\mathrm{~d}, 1 \mathrm{H}, J=2 \mathrm{~Hz}), 8.39(\mathrm{t}, 1 \mathrm{H}, J$ $=1 \mathrm{~Hz}), 8.29(\mathrm{~d}, 1 \mathrm{H}, J=10 \mathrm{~Hz}), 8.23(\mathrm{t}, 1 \mathrm{H}, J=2 \mathrm{~Hz}), 8.08(\mathrm{~d}, 2 \mathrm{H}$, $J=8 \mathrm{~Hz}), 7.92(\mathrm{~d}, 2 \mathrm{H}, J=8 \mathrm{~Hz}), 7.86(\mathrm{dd}, 1 \mathrm{H}, J=10 / 2 \mathrm{~Hz}), 7.76$ $(\mathrm{dd}, 1 \mathrm{H}, J=8 / 2 \mathrm{~Hz}), 7.73(\mathrm{~d}, 1 \mathrm{H}, J=8 \mathrm{~Hz}), 6.76(\mathrm{~d}, 1 \mathrm{H}, J=3 \mathrm{~Hz})$, 6.36-6.22 (AB-syst., 2H, $\mathrm{NCH}_{2}$ ), 3.97 (s, 3H, $\left.\mathrm{OCH}_{3}\right) .{ }^{13} \mathrm{C} \mathrm{NMR}$ $\left(\mathrm{DMSO}-\mathrm{d}_{6}\right): \delta(\mathrm{ppm}) 191.38,159.89,147.30,147.01,141.20$, 135.50, 134.16, 133.18, 132.84, 132.03, 130.84, 130.84, 129.45, 128.29, 127.76, 126.01, 125.23, 124.22, 123.87, 121.11, 97.56, 56.70, 56.53. Anal. calcd for $\mathrm{C}_{25} \mathrm{H}_{18} \mathrm{Br}_{2} \mathrm{ClN}_{3} \mathrm{O}_{2}$ : C 51.09, H 3.09, N 7.15\%; found: C 51.11, H 3.05, N 7.31\%. HRMS (ESI ${ }^{+}$) $m / z$ calcd for $\mathrm{C}_{25} \mathrm{H}_{18} \mathrm{BrClN}_{3} \mathrm{O}_{2}[\mathrm{M}-\mathrm{Br}]^{+}: 506.0271$ (75\%), 507.0304 (21\%), 508.0270 (100\%), 509.0294 (27\%), 510.0232 (27\%), 511.0265 (8\%); found: 506.0282 (85\%), 507.0306 (28\%), 508.0267 (100\%), 509.0285 (33\%), 510.0238 (31\%), 511.0261 (7\%).

\section{Biological activity}

Cell culture. MCF-7, MCF-10, PC-3, CAOV-3 and T1074 cell line were originally obtained from the American Type Culture Collection (ATCC; Manassas, VA) as shown in Table 5. The cells were cultured in RPMI-1640 medium. The medium was supplemented with $10 \%$ fetal bovine serum (FBS) and 1\% antibiotics (penicillin-streptomycin) and incubated at $37{ }^{\circ} \mathrm{C}$ in humidified $\mathrm{CO}_{2}$ incubator with $5 \% \mathrm{CO}_{2}$. The medium was changed twice a week until confluent cell monolayer was formed and observed under an inverted microscope. ${ }^{45}$

Cellular viability assay (MTT assay). The inhibitory effect of compounds was determined by an MTT assay, in which $5 \times 10^{3}$ cells per well were seeded in 96-well plates and kept for 24 hours (h) at $37{ }^{\circ} \mathrm{C}$ with $5 \% \mathrm{CO}_{2}$ saturation. After this incubation, a serial dilution of different concentrations of compounds were prepared and transferred to the 96 well plates containing the seeded cells and incubated for another $24 \mathrm{~h}$ at $37{ }^{\circ} \mathrm{C}$ and $5 \%$ $\mathrm{CO}_{2}$. Subsequently, $20 \mu \mathrm{L}$ of MTT (3-[4,5-dimethylthiazol-2-yl]2,5-diphenyltetrazolium bromide, $5 \mathrm{mg} \mathrm{mL}^{-1}$ ) was added to the treated cells in a dark place, covered with foil and incubated for $4 \mathrm{~h}$. All media was discharged and a total of $100 \mu \mathrm{L}$ volume of DMSO was poured into each well until the purple formazan crystals dissolved. The plate was measured using a microplate reader at absorbance $570 \mathrm{~nm}$. The experiment was conducted in triplicate to evaluate the $\mathrm{IC}_{50}$. The percentage of cytotoxicity was determined using the following formula:

$$
\text { Cell viability } \%=\frac{X}{X_{\mathrm{c}}} \times 100 \%,
$$

where $X$ is the absorbance of treated cells, and $X_{\mathrm{c}}$ is the absorbance of the control group (untreated cells). Based on the reference, cytotoxicity responses were qualitatively rated as severe, moderate, slight and non-cytotoxic when the cytotoxicity percentage was $<30 \%, 30-59 \%, 60-90 \%$ and $>90 \%$, respectively. ${ }^{46}$

\section{Antioxidant activity}

DPPH assay. The assay was performed in a 96-well microtiter plate according to a modified method by Orhan et al. ${ }^{47}$ and Brem et $a .^{48}$ A solution of $30 \mu \mathrm{L} \mathrm{DPPH}\left(1.5 \mathrm{mg} \mathrm{mL}^{-1}\right)$ in $70 \mu \mathrm{L}$ DMSO was treated with different concentrations of the compounds, ranging from 15.6 to $1000 \mu \mathrm{g} \mathrm{mL}{ }^{-1}$. Ascorbic acid was used as positive control, while the last row of the plate only contained blank samples of DPPH in DMSO as reference. The plate was incubated for $30 \mathrm{~min}$ in the dark and the decrease in absorbance at $517 \mathrm{~nm}$ was determined using Tecan micro plate reader (Infinite M200PRO). The radical scavenging activity was calculated using the following formula:

$$
\text { Inhibition }=\frac{A_{0}-A_{1}}{A_{0}} \times 100 \%,
$$

where $A_{0}$ is the absorbance of the DPPH radical in the blank sample and $A_{1}$ the corresponding absorbance in presence of the sample. The correlation between each concentration and its scavenging was plotted on a graph, and the $\mathrm{IC}_{50}$ was determined

Table 5 Normal and cancerous cell lines

\begin{tabular}{lll}
\hline Cell lines & Classification & Source \\
\hline MCF-7 & Breast cancer cells & American Type Culture Collection (ATCC) \\
MCF-10 & Normal breast cancer cells & \\
CAOV-3 & Ovarian cancer cells & \\
T1074 & Normal ovarian cancer cells & \\
PC-3 & Prostate adenocarcinoma cells
\end{tabular}


from the graph as the concentration required to reduce the DPPH absorption by $50 \% .^{49}$

FRAP assay. The determination of the total antioxidant activity followed a modified method of Benzie and Strain (1999). ${ }^{50}$ The ferric reducing antioxidant power (FRAP) was determined by using freshly prepared reagent based on mixing $300 \mathrm{mM}$ acetate buffer, $10 \mathrm{mM}$ TPTZ (2,4,6-tripyridyl-s-triazine) and a solution combining $20 \mathrm{mM}$ iron(III) chloride $\left(\mathrm{FeCl}_{3} \times\right.$ $6 \mathrm{H}_{2} \mathrm{O}$ ) and $40 \mathrm{mM} \mathrm{HCl}$ in a ratio of $10: 1: 1$. For measurement, $10 \mu \mathrm{L}$ of samples $\left(1 \mathrm{mg} \mathrm{mL}^{-1}\right)$ and $300 \mu \mathrm{L}$ FRAP reagent were mixed in multiwell plates and readings of the coloured product (ferrous tripyridyltriazine complex) were taken at $593 \mathrm{~nm}$. Ascorbic acid and ferrous sulphate were used as control and standard, respectively. The FRAP activity was calculated as ferrous equivalents (FE) at a single concentration of $1 \mathrm{mg} \mathrm{mL} \mathrm{m}^{-1}$ and the FE was calculated from the standard curve of $\mathrm{FeSO}_{4}{ }^{.11} \mathrm{~A}$ linear calibration curve covering the range of 100 and $1000 \mathrm{mM}$ $\mathrm{FeSO}_{4}$ was used to convert the absorption readings to FE. The results were expressed as $\mathrm{mM} \mathrm{Fe}(\mathrm{II}) / \mathrm{g}$ dry weight of the compound.

\section{Statistical analysis}

All analyses were performed in triplicates. Results were expressed as a means \pm standard deviation (SD).

\section{Conclusions}

Acridine-based imidazolium cations are easily accessible compounds, which can exhibit promising therapeutic potential for cancer therapy. High reaction yields and simple purification by crystallization provide economic viability, while the Ullmann-based synthesis of the acridine core provides structural diversity for the heterocyclic core. None of the investigated compounds exhibited significant cell toxicity against human non-cancer cell lines. This suggests a safe application of the potential drug. Unlike the cancer drugs Tamoxifen and Paclitaxel, the therapeutic potential of acridine-based imidazolium salts is highly specific for certain cancer types, requesting for different drugs for the therapy of breast, prostate and ovarian cancers. Nonetheless, for all these cancers promising candidates, matching the efficacy of current market drugs Tamoxifen and Paclitaxel, have been identified. The fluorescence of the acridine core might enable studies on the distribution of drug molecules in living tissue, as almost all compounds show visible fluorescence upon low energy UV excitation. However, additional studies are required to evaluate the fluorescence in view of biological background luminescence.

\section{Conflicts of interest}

There are no conflicts to declare.

\section{Acknowledgements}

The authors thank Mr Goh Ean Wai for assistance in the recording of NMR spectra and gratefully acknowledge financial support from the University of Malaya under research grants PG108-2016A and CR011-2015.

\section{Notes and references}

1 X. Lang, L. Li, Y. Chen, Q. Sun, Q. Wu, F. Liu, C. Tan, H. Liu, C. Gao and Y. Jiang, Bioorg. Med. Chem., 2013, 21, 4170-4177.

2 B. Li, C.-M. Gao, Q.-S. Sun, L.-L. Li, C.-Y. Tan, H.-X. Liu and Y.-Y. Jiang, Chin. Chem. Lett., 2014, 25, 1021-1024.

3 J. R. Goodell, A. V. Ougolkov, H. Hiasa, H. Kaur, R. Remmel, D. D. Billadeau and D. M. Ferguson, J. Med. Chem., 2008, 51, 179-182.

4 B. F. Dickens, W. B. Weglicki, P. A. Boehme and T. I. Mak, J. Mol. Cell. Cardiol., 2002, 34, 129-137.

5 R. Kalirajan, M. H. M. Rafick, S. Sankar and S. Jubie, Sci. World J., 2012, 2012, 165258.

6 R. Kalirajan, V. Kulshrestha, S. Sankar and S. Jubie, Eur. J. Med. Chem., 2012, 56, 217-224.

7 W.-J. Song, X.-D. Yang, X.-H. Zeng, X.-L. Xu, G.-L. Zhang and H.-B. Zhang, RSC Adv., 2012, 2, 4612-4615.

8 S. M. Sondhi, J. Singh, R. Rani, P. P. Gupta, S. K. Agrawal and A. K. Saxena, Eur. J. Med. Chem., 2010, 45, 555-563.

9 B. Philippe, B. Johann, G. Thomas and T. Martin, Anti-Cancer Agents Med. Chem., 2007, 7, 139-169.

10 I. Antonini, Med. Chem. Rev.-Online, 2004, 1, 267-290.

11 B. C. Baguley, L. P. Wakelin, J. D. Jacintho and P. Kovacic, Curr. Med. Chem., 2003, 10, 2643-2649.

12 R. Kalirajan, V. Kulshrestha, S. Sankar and S. Jubie, Eur. J. Med. Chem., 2012, 56, 217-224.

13 A. Vik, E. Hedner, C. Charnock, L. W. Tangen, Ø. Samuelsen, R. Larsson, L. Bohlin and L.-L. Gundersen, Bioorg. Med. Chem., 2007, 15, 4016-4037.

14 C. G. Fortuna, V. Barresi, G. Berellini and G. Musumarra, Bioorg. Med. Chem., 2008, 16, 4150-4159.

15 A. Prasad, G. Raju, V. Sivalingam, A. Girdhar, M. Verma, A. Vats, V. Taneja, G. Prabusankar and B. K. Patel, Sci. Rep., 2016, 6, 39490.

16 R. A. Haque, N. Hasanudin, M. A. Iqbal, A. Ahmad, S. Hashim, A. Abdul Majid and M. B. K. Ahamed, J. Coord. Chem., 2013, 66, 3211-3228.

17 N. Hadei, E. A. B. Kantchev, C. J. O'Brie and M. G. Organ, Org. Lett., 2005, 7, 1991-1994.

18 J. Kaur and P. Singh, Expert Opin. Ther. Pat., 2011, 24, 437454.

19 G. Raju, S. Vishwanath, A. Prasad, B. K. Patel and G. Prasusankar, J. Mol. Struct., 2016, 1107, 291-299.

20 N. N. Al-Mohammed, R. S. D. Hussen, Y. Alias and Z. Abdullah, RSC Adv., 2015, 5, 2869-2881.

21 A. A. Salman, M. Tabandeh, T. Heidelberg, R. S. D. Hussen and H. M. Ali, Carbohydr. Res., 2015, 412, 28-33.

22 R. Rohini, C. K. Lee, J. T. Lu and I. J. Lin, J. Chin. Chem. Soc., 2013, 60, 745-754.

23 R. Csuk, A. Barthel and C. Raschke, Tetrahedron, 2004, 60, 5737-5750.

24 L. M. Mironovich, L. S. Ageeva and A. Y. Podol'nikova, Russ. J. Gen. Chem., 2016, 86, 420-422.

25 J. M. Rippe, Lifestyle Medicine, CRC Press, 2nd edn, 2013. 
26 T. Nguyen, The Committee on Diet, Food and Cancer: A Guide to Understanding the Secondary Causes of Cancer, 2015.

27 K. Radošević, M. Cvjetko, N. Kopjar, R. Novak, J. Dumić and V. G. Srček, Ecotoxicol. Environ. Saf., 2013, 92, 112-118.

28 M. Cai, Y. Liang, M. Yao, Y. Xia, F. Zhou and W. Liu, ACS Appl. Mater. Interfaces, 2010, 2, 870-876.

29 A. Zugic, I. Jeremic, A. Isakovic, I. Arsic, S. Savic and V. Tadic, PLoS One, 2016, 11, e0146342.

30 A. Žugić, S. Đorđević, I. Arsić, G. Marković, J. Živković, S. Jovanović and V. Tadić, Ind. Crops Prod., 2014, 52, 519527.

31 V. Sorrenti, L. Salerno, C. Di Giacomo, R. Acquaviva, M. A. Siracusa and A. Vanella, Nitric Oxide, 2006, 14, 45-50.

32 R. A. Haque, M. A. Iqbal, P. Asekunowo, A. M. S. A. Majid, M. B. Khadeer Ahamed, M. I. Umar, S. S. Al-Rawi and F. S. R. Al-Suede, Med. Chem. Res., 2013, 22, 4663-4676.

33 X.-L. Xu, C.-L. Yu, W. Chen, Y.-C. Li, L.-J. Yang, Y. Li, H.-B. Zhang and X.-D. Yang, Org. Biomol. Chem., 2015, 13, 1550-1557.

34 J. Ranke, S. Stolte, R. Störmann, J. Arning and B. Jastorff, Chem. Rev., 2007, 107, 2183-2206.

35 L.-X. Liu, X.-Q. Wang, B. Zhou, L.-J. Yang, Y. Li, H.-B. Zhang and X.-D. Yang, Sci. Rep., 2015, 5, 13101.

36 Z. He, K. Huang, F. Xiong, S.-F. Zhang, J.-R. Xue, Y. Liang, L.-H. Jing and D.-B. Qin, J. Organomet. Chem., 2015, 797, 67-75.

37 M. C. Gimeno, A. Laguna and R. Visbal, Organometallics, 2012, 31, 7146-7157.

38 A. Elangovan, H.-H. Chiu, S.-W. Yang and T.-I. Ho, Org. Biomol. Chem., 2004, 2, 3113-3118.
39 P. Sandeep and P. B. Bisht, Chem. Phys., 2006, 326, 521-526. 40 Z. Cheng, B. Yang, M. Yang and B. Zhang, J. Braz. Chem. Soc., 2014, 25, 112-118.

41 A. J. Boydston, P. D. Vu, O. L. Dykhno, V. Chang, A. R. Wyatt, A. S. Stockett, E. T. Ritschdorff, J. B. Shear and C. W. Bielawski, J. Am. Chem. Soc., 2008, 130, 3143-3156.

42 M. Staderini, M. L. Bolognesi and J. C. Menéndez, Adv. Synth. Catal., 2015, 357, 185-195.

43 M. Staderini, N. Cabezas, M. L. Bolognesi and J. C. Menendez, Tetrahedron, 2013, 69, 1024-1030.

44 C. Gao, B. Lin, B. Zhang, Q. Sun, L. Li, X. Li, G. Chen, C. Tan, H. Liu and Y. Jiang, Bioorg. Med. Chem., 2015, 23, 1800-1807.

45 S. N. Jayash, N. M. Hashim, M. Misran and N. Baharuddin, PeerJ, 2016, 4, e2229.

46 S. N. Jayash, N. M. Hashim, M. Misran and N. A. Baharuddin, J. Biomed. Mater. Res., 2017, 105, 398-407.

47 I. Orhan, M. Kartal, Q. Naz, A. Ejaz, G. Yilmaz, Y. Kan, B. Konuklugil, B. Şener and M. I. Choudhary, Food Chem., 2007, 103, 1247-1254.

48 B. Brem, C. Seger, T. Pacher, M. Hartl, F. Hadacek, O. Hofer, S. Vajrodaya and H. Greger, Phytochemistry, 2004, 65, 27192729.

49 H. S. Kareem, A. Ariffin, N. Nordin, T. Heidelberg, A. AbdulAziz, K. W. Kong and W. A. Yehye, Eur. J. Med. Chem., 2015, 103, 497-505.

50 F. Benzie and J. Strain, Methods Enzymol., 1999, 299, 15-27.

51 N. Nordin, N. Syam Mohan, A. Zajmi, N. S. M. Yazid, M. A. Rahman, F. A. A. Omer and H. Omar, Sains Malays., 2014, 43, 1515-1521. 